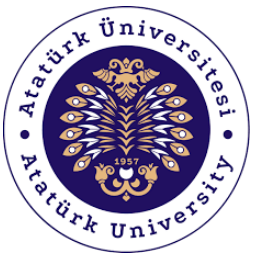

Doğu Coğrafya Dergisi

Haziran-2021, Y1l: 26, Say1: 45, Sayfa: 235-256

Eastern Geographical Rewiew

June-2021 Volume: 26, Numbers: 45, Page: 235-256

DOİ: https://doi.org/ 10.17295/ataunidcd.885546

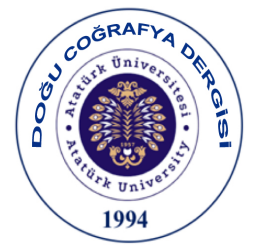

Atıf/Citiation

Şahbaz, H., (2021), 2000 y1lı sonrası ülke içi göçlerde Kütahya ilinin yeri. Doğu Coğrafya Dergisi 26(45), 235-256

\title{
2000 YILI SONRASI ÜLKE İÇİ GÖÇLERDE KÜTAHYA İLİNIN YERİ
}

The Place of Kütahya Province in Domestic Migrations After 2000

Hüseyin ŞAHBAZ*

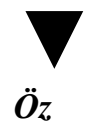

1927-2020 yılları arasında Türkiye nüfusu yaklaşık 6,13 kat artarken Kütahya ilinin nüfusu ise sadece 2,17 kat artmıştır. 1975-2020 yılları arasındaki net göç sayısına göre Kütahya, Afyonkarahisar'dan sonra Ege Bölgesi'nin en fazla göç veren ikinci ilidir. Ayrıca 31 Aralık 2020 tarihi itibarıla başka bir ile kayıtlı olduğu halde araştırma sahasında ikamet eden nüfustan, araştırma sahası nüfusuna kayıtlı olduğu halde başka illerde yaşayan nüfus arasındaki farka bakıldı̆̆ında, Kütahya ilinin 164.331 kişilik bir göç açı̆̆ı olduğu görülmektedir. Inceleme alanının gerek kendi içinde meydana gelen nüfus hareketlerinde ve gerekse başka yerlere verdiği göçlerde strasılla; işsizlik ve ekonomik sorunlar, ĕgitim ve sağlık hizmetlerine erişim konusunda yaşanan sıkıntılar ile büyük yerleşim yerlerinin sosyal ve kültürel açıdan daha çekici gelmesi gibi sebepler vardır. Insanları göçe iten bu sebepler daha çok kırsal yerleşmelerde görüldügüunden ildeki göçlerin yönünün de, gerek araştırma sahası içindeki ve gerekse araştırma sahası dışındaki, şehirlere doğru olduğunu söylemek mümkündür. Nitekim kırsal ve kentsel nüfus açısından ilin Cumhuriyet Dönemi'ndeki geçmişine bakılacak olursa, kırsal nüfus oranının 1950 yılında \% 85,8 iken 2020 yılına gelindiğinde \% 28,1'e kadar gerilemesi de bunu doğrulamaktadır. Buna göre saha içinde meydana gelen göçler nedeniyle; Kütahya, Tavşanll, Simav, Emet ve Gediz gibi şehirlerin nüfusu artmıştır. Bunun sonucunda inceleme alanındaki kentsel nüfus oranı 1950 yılında \% 14,2 iken 2020 yılına gelindiğinde ise \% 71,9'a kadar çıkmıştır. Araştırma sahası dışına yapılan göçler ise daha çok; İzmir, İstanbul, Bursa, Manisa, Uşak, Eskişehir, Antalya, Ankara ve Kocaeli gibi illere yapılmıştır. Inceleme alanındaki sanayi yatırımlarının artan il nüfusunun istihdam ihtiyacını yeterince karşılayamaması, bu göçlerin başlıca sebebidir. Dahası 2004 yılından başlayarak ilde binlerce kişiye istihdam sağlayan kamu iktisadi teşebbüslerinin özelleştirilmesi, bu göçlerin hızını önemli ölçüde artırmıştır.

Anahtar Kelimeler: Kütahya İli, Göç, İç Göç.

\section{Abstract}

While the population of Turkey increased approximately 6.13 times between 1927 and 2020, the population of Kütahya increased only 2.17 times. According to the exact number of immigrants between 1975-2020, Kütahya is the second province in the Aegean Region with the highest number of immigrants after Afyonkarahisar. In addition, as of December 31, 2020, considering the difference between the population living in the research area although registered to another and the population living in other provinces although registered to the area in which the study is conducted, it is seen that Kütahya has a migration deficit of 164,331 people. In the population movements that occur within the research area

\footnotetext{
* Afyonkarahisar İl Milli Eğitim Müdürlüğü, huseyiniyesuh@gmail.com, 0000-0002-4808-0746
}

Dergiye Geliş Tarihi: 28.02.2021

Yayına Kabul Tarihi: 20.06.2021 
and the migration to other places, respectively; there are reasons such as unemployment and economic problems, difficulties in accessing education and health services, and the social and cultural attractiveness of large settlements. Since these reasons that push people to migrate are mostly seen in rural areas, it is possible to say that the direction of migration in the province is towards cities both within and outside the study area. As a matter of fact, if we look at the history of the province in the Republic Period in terms of rural and urban population, the decrease in the ratio of rural population from $85.8 \%$ in 1950 to $28.1 \%$ in 2020 confirms that the direction of migration in the province is towards cities both within and outside the study area. Accordingly, due to migrations occurring in the field; the population of cities such as Kütahya, Tavşanl, Simav, Emet and Gediz has increased. As a result, the urban population ratio in the research area increased from $14.2 \%$ in 1950 to $71.9 \%$ in 2020. Migrations outside the research area were mostly made to provinces such as Izmir, Istanbul, Bursa, Manisa, Uşak, Eskişehir, Antalya, Ankara and Kocaeli. The main reason for these migrations is that industrial investments in the field cannot adequately meet the employment needs of the increasing province population. Moreover, the privatization of state-owned enterprises that employed thousands of people in the province since 2004 has significantly increased the pace of these migrations.

Keywords: Kütahya Province, Migration, Internal Migration. 


\section{Giriş}

Göç, insanların, sosyal, ekonomik, siyasi veya doğal nedenlerden dolayı coğrafi olarak yer değiştirmesi biçiminde tanımlanabilir. Göçün biçimi ne olursa olsun her türlü nüfus hareketi, göç tanımı içinde kendisine yer bulur. İnsanlar, bazen çalışmak, iş aramak ve daha konforlu bir hayat sürebilmek için gönüllü olarak doğup büyüdükleri yerlerden ayrılırken, bazen de savaşlar, baskılar, sürgünler veya doğal afetler gibi zorunlu sebeplerle, hayatta kalabilmek için yaşadıkları yerlerden göç ederler. Bu yer değiştirme uluslararası bir sınırı geçmek biçiminde olabildiği gibi, aynı ülke içinde de olabilir (Adıgüzel, t.y.: 12). Türkiye'deki iç göç olaylarından etkilenen illerden birisi de Kütahya'dır.

Kütahya ili coğrafi açıdan, Ege Bölgesi'nin İç Batı Anadolu Bölümü’nde yer almaktadır. Bu saha; kuzeyde Bursa ve Bilecik; kuzeydoğu ve doğuda Eskişehir, güneydoğuda Afyonkarahisar, güneyde Uşak, batıdan Kütahya, güneybatıda Manisa ve batıdaysa Balıkesir illeriyle çevrilidir (Harita 1). Matematiksel konum açısından $38^{\circ} 48^{\prime}-39^{\circ} 53^{\prime}$ kuzey enlemleri ile $28^{\circ} 37^{\prime}-30^{\circ} 27^{\prime}$ doğu boylamları arasında yer alan sahanın yüzölçümüyse $11.634 \mathrm{~km}^{2}$ 'dir.

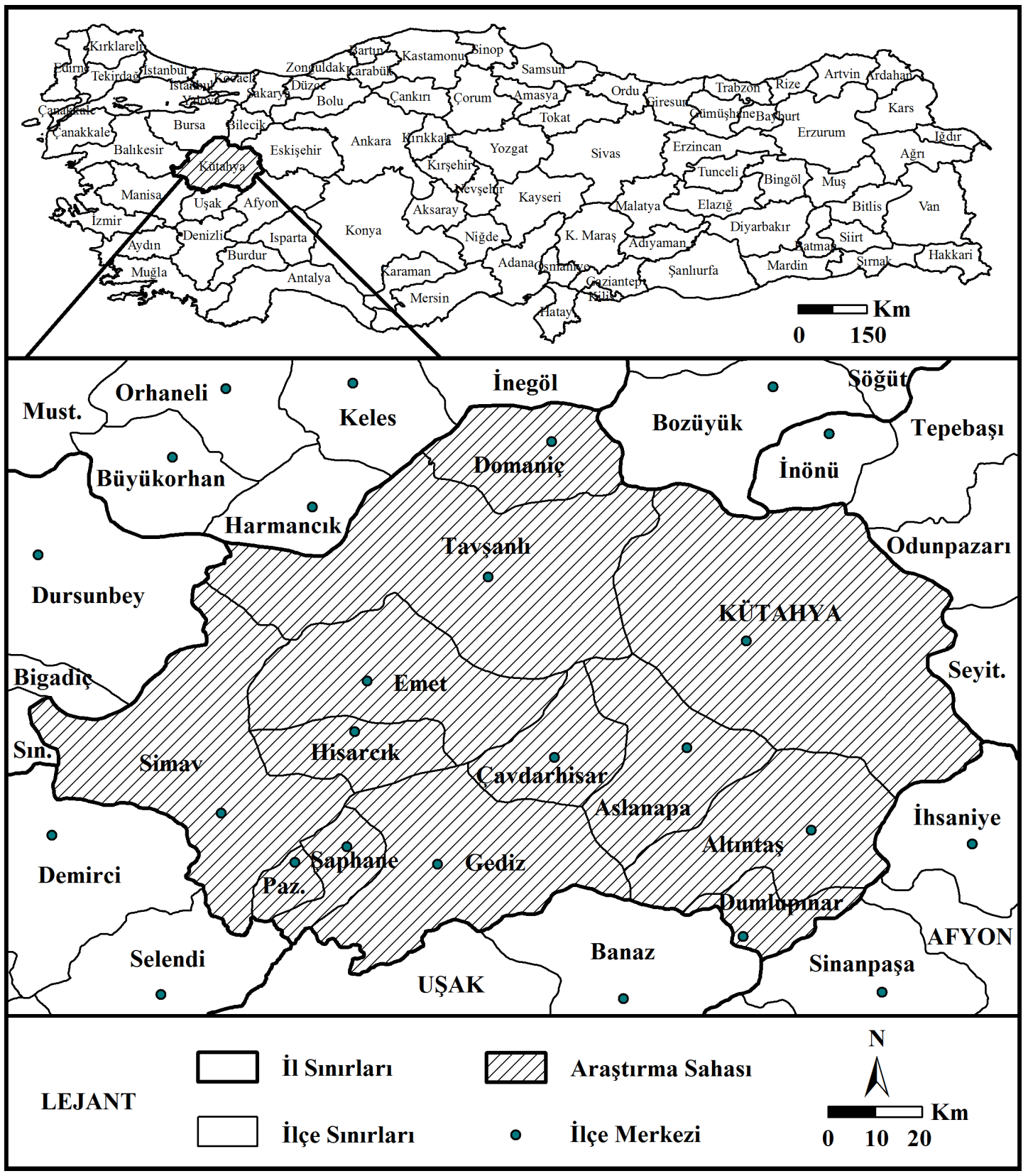

Harita 1. Kütahya İlinin; Konumu, Sınırları ve İdari Haritası 
Türkiye İstatistik Kurumu (TÜiK) Adrese Dayalı Nüfus Kayı Sistemi (ADNKS) verilerine göre 31 Aralık 2020 tarihi itibarıyla toplam 576.688 kişinin yaşadığı inceleme alanında idari açıdan; Kütahya Merkez, Tavşanl, Simav, Emet, Pazarlar, Domaniç, Dumlupınar, Çavdarhisar, Aslanapa, Altıntaş, Şaphane, Hisarcık ve Gediz olmak üzere 13 ilçe bulunmaktadır. Bu ilçelerin merkezi konumunda olan yerleşmeleri, coğrafi açıdan pek çok şehir araştırmacısının kır-kent ayrımında temel ölçüt olarak kabul ettiği 10.000 nüfus kriteri (Darkot, 1967: 3) açısından, 31 Aralık 2020 tarihine ilişkin TÜIK' in ADNKS verilerine göre değerlendirmek mümkündür. Buna göre sahadaki yerleşmelerden; Kütahya (253.335 kişi), Tavşanlı (72.723 kişi), Simav (26.436 kişi), Gediz (24.669 kişi) ve Emet (11.405 kişi)'in şehir; diğerlerininse kasaba niteliği taşıdığı görülmektedir.

Kütahya, yer altı kaynakları bakımından zengin bir ildir. Nitekim MTA'nın yaptığı çalışmalar sonucunda il ve yakın çevresinde önemli metalik maden ve endüstriyel hammadde kaynakları ile linyit oluşumları ortaya çıkarılmıştır. Bunlar; bor ve kaolen başta olmak üzere gümüş, krom, alunit, antimuan, bakır, kurşun, çinko, demir, manganez, manyezit, çimento hammaddeleri, feldispat, jips, florit ve kum-çakıldır. (MTA, 2010).

Özellikle zengin kil yatakları nedeniyle araştırma sahası; Frig, Helenistik, Roma, Bizans, Osmanlı döneminde önemli bir seramik üretim merkezi olmuş (Duysak vd., 2014: 60) ve bu durum Cumhuriyet Dönemi'nde de devam etmiştir. Organik olmayan maddelerden oluşan karışımların şekillendirilmesi, sırlanması ve pişirilmesi süreçleri ile elde edilen sert ürünlere genel olarak seramik adı verilir. Bu genelleme ile bakıldığında; çömlek, tuğla, kiremit, fayans, çimento, cam, porselen ve çini gibi çok çeşitli ürünler seramik kapsamı içerisinde yer alır (İssi ve Yurdakul, 2002: 74).

$\mathrm{Bu}$ alanda Cumhuriyet Dönemi'nde araştırma sahasındaki ilk büyük sanayi tesisi, Nuri Conker ve arkadaşları tarafından 1926 yılında Marsilya tipi kiremit üretmek maksadıyla kurulan ve 1935 yılında Sümerbank tarafından satın alınan, Sümerbank Seramik Fabrikası'dır. Onu 1948 ilâ 1954 yılları arasında ilde 4 tane daha tuğla ve kiremit fabrikasının kurulması takip etmiştir. 1970 yılına gelindiğinde sahada Kütahya Porselen ve Evliya Çelebi Çini adlarında 2 fabrika daha faaliyete geçmiştir. Bunlardan Kütahya Porselen, bugün dünyanın en önemli porselen üreticilerinden birisidir. Bunlardan başka 1973 yılında Hatipoğlu Güneş Kiremit Fabrikası, 1982 yılında Güral Kiremit Fabrikası, 1983 yılında Altın Çini ve Seramik Fabrikası ve 1989 yılında ise Kütahya Seramik Fabrikası, araştırma sahasında bu alanda yapılan diğer önemli yatırımlar olmuştur (Çetintaş, 2017: 3-13).

Araştırma sahasının ikinci önemli yer altı kaynağı, ilin ekonomik gelişmesinde önemli bir rol oynayan, linyittir. Bu kömür türünün çıkarılmasına yönelik ilk devlet girişimi, 1938 yılında Etibank’a bağlı olarak faaliyete geçen Değirmisaz İşletmesi'dir. Bunu 1939 yılında faaliyete geçen Tunçbilek İşletmesi, 1951 yılında faaliyete geçen Gediz Linyit İşletmesi takip etmiştir. 1954 yılında Tunçbilek Havzası'ndan istihsal edilen düşük kaliteli kömürlerin değerlendirilmesi amacıyla Tunçbilek Termik Santrali faaliyete geçirilmiştir. 1955 yılında bir halk teşebbüsü olan Gediz-Gökler İşletmesi ve 1960 yılında Seyitömer Linyit İşletmesi faaliyete geçmiştir. Bunlardan 1966 yılında Değirmisaz Linyit İşletmesi, rezervi tükendiği için kapatılmış, 1973 yıllındaysa Seyitömer Havzası'ndan istihsal edilen düşük kaliteli kömürlerin değerlendirilmesi amacıyla Seyitömer Termik Santrali faaliyete geçirilmiştir (Çetintaş, 2017: 3-8). Seyitömer Havzası'ndan istihsal edilen linyit hammaddesini kullanılarak ilde kurulan bir diğer sanayi tesisi de 1961 yılında üretime başlayan, Kütahya Azot Fabrikası'dır (Yener, 1980: 35).

İldeki diğer önemli yer altı kaynaklarının değerlendirilmesi amacıyla 1958 yılında Emet ilçesinde ülkenin bor minerallerinin önemli bir bölümünü oluşturan Etibank-Emet Kolemanit Maden İşletmesi, 1976 yılında manyezit cevherlerinin değerlendirilmesi maksadıyla Kümaş Kütahya Manyezit İşletmesi, 1987 yılında sahadaki gümüş madenlerinin işletilmesi maksadıyla da Eti Gümüş Fabrikası faaliyete geçirilmiştir (Çetintaş, 2017: 3-8).

Araştırma sahasındaki toplam arazi varlı̆̆ 1.187 .500 ha olup bunun \% 29’u (346.354 ha) kültüre elverişlidir. Bunun da \% 23,3'ü (80.733 ha) sulu, geri kalanıysa kuru tarım arazisidir. Kuru tarım arazisinin oranının fazla olması nedeniyle ilde daha çok hububat ekimi yapılmaktadır. Bundan başka sulanabilen alanlardaysa şeker pancarı yetiştiriciliği ön plana çıkmaktadır (Kütahya İl Tarım ve Orman Müdürlügü̆, t.y.). Buna bağlı olarak da sahada 1954 yılında Kütahya Şeker Fabrikası hizmete açılmıştır (Türkşeker, t.y.).

Üniversiteler, kuruldukları kentlerin; ekonomik, sosyal ve kültürel yapısı üzerinde önemli etkilere sahiptirler. Özellikle üniversite öğrencilerinin yapmış olduğu harcamalar, kent ekonomisine canlılık kazandıran önemli bir harcama grubunu oluşturmaktadır. 1992 yılında araştırma sahasında kurulan Dumlupınar Üniversitesi de Kütahya ilinin ekonomik ve kültürel gelişimine önemli katkılar sağlayan kurumlardan bir diğeridir (Demireli ve Taşkın, 2013: 321). 
Ancak tüm bu gelişmelere rağmen Cumhuriyet Dönemi’nde inceleme alanındaki nüfus artışının ülkeninkiyle uyuşmadığı da görülmektedir. Nitekim nüfus geçmişine bakıldığındaysa (Tablo 1), Türkiye'de ilk nüfus sayımının yapıldığı 1927 yılında sahada 265.706 kişi yaşarken bu sayı aradan geçen 93 yılda sadece 2,17 kat artmıştır. Oysaki aynı süreçte Türkiye nüfusu, 13.648.270 kişiden 83.614.362'ye ulaşmış ve buna göre ülke nüfusundaki artış, yaklaşık 6,13 kat olmuştur. Bu da sahanın önemli ölçüde göç verdiğini göstermektedir.

Tablo 1. Sayım Yıllarına Göre Kütahya İli ve Türkiye Nüfusunun Karşılaştırma Tablosu (1927-2020)

\begin{tabular}{|c|c|c|c|c|c|c||}
\hline \multirow{3}{*}{ Yıllar } & \multicolumn{3}{|c|}{ Kütahya İlinde Nüfusun } & \multicolumn{3}{c||}{ Türkiye'de Nüfusun } \\
\cline { 2 - 7 } & Sayısı & $\begin{array}{c}\text { Artan / } \\
\text { Eksilen Sayısı }\end{array}$ & $\begin{array}{c}\text { Dönemsel } \\
\text { Değişim \%'si }\end{array}$ & Sayısı & $\begin{array}{c}\text { Artan / } \\
\text { Eksilen Sayısı }\end{array}$ & $\begin{array}{c}\text { Dönemsel } \\
\text { Değişim \%'si }\end{array}$ \\
\hline 1927 & 265.706 & - & - & 13.648 .270 & - & - \\
\hline 1935 & 250.456 & -15.250 & $-5,7$ & 16.158 .018 & 2.509 .748 & 18,4 \\
\hline 1940 & 259.305 & 8.849 & 3,5 & 17.820 .950 & 1.662 .932 & 10,3 \\
\hline 1945 & 277.272 & 17.967 & 6,9 & 18.790 .174 & 969.224 & 5,4 \\
\hline 1950 & 305.170 & 27.898 & 10,1 & 20.947 .188 & 2.157 .014 & 11,5 \\
\hline 1955 & 330.978 & 25.808 & 8,5 & 22.104 .431 & 1.157 .243 & 5,5 \\
\hline 1960 & 367.753 & 36.775 & 11,1 & 27.754 .820 & 5.650 .389 & 25,6 \\
\hline 1965 & 398.081 & 30.328 & 8,2 & 31.391 .421 & 3.636 .601 & 13,1 \\
\hline 1970 & 439.967 & 41.886 & 10,5 & 35.605 .176 & 4.213 .755 & 13,4 \\
\hline 1975 & 470.423 & 30.456 & 6,9 & 40.347 .719 & 4.742 .543 & 13,3 \\
\hline 1980 & 497.089 & 26.666 & 5,7 & 44.736 .957 & 4.389 .238 & 10,9 \\
\hline 1985 & 543.384 & 46.295 & 9,3 & 50.664 .458 & 5.927 .501 & 13,2 \\
\hline 1990 & 578.020 & 34.636 & 6,4 & 56.473 .035 & 5.808 .577 & 11,5 \\
\hline 1997 & 643.117 & 65.097 & 11,3 & 62.865 .574 & 6.392 .539 & 11,3 \\
\hline 2000 & 656.903 & 13.786 & 2,1 & 67.803 .927 & 4.938 .353 & 7,9 \\
\hline 2007 & 583.910 & -72.993 & $-11,1$ & 70.586 .256 & 2.782 .329 & 4,1 \\
\hline 2010 & 590.496 & 6.586 & 1,1 & 73.722 .988 & 3.136 .732 & 4,4 \\
\hline 2015 & 571.463 & -19.033 & $-3,2$ & 78.741 .053 & 5.018 .065 & 6,8 \\
\hline 2020 & 576.688 & 5.225 & 0,9 & 83.614 .362 & 4.873 .309 & 6,2 \\
\hline
\end{tabular}

Kaynak: DİE’nin Genel Nüfus Sayımı sonuçları ile TÜIK'in ADNKS veri tabanından yararlanılarak hazırlanmıştır.

Sahanın göç verdiğinin bir diğer kanıtı da, sayım yıllarına göre Kütahya ilinde nüfusun dönemsel değişim oranlarını gösteren, Şekil 1'de de görüleceği üzere özellikle 1997 yılından sonra görülen eksi ya da çok düşük değerlerdir. Nitekim nüfusun dönemsel değişim oranı; 1997-2000 yılları arasında \% 2,1, 2000-2007 y1lları arasında \% -11,1, 2007-2010 yılları arasında \% 1,1, 2010-2015 yılları arasında \% -3,2 ve 2015-2020 y1lları arasındaysa \% 0,9 oranında gerçekleşmiştir.

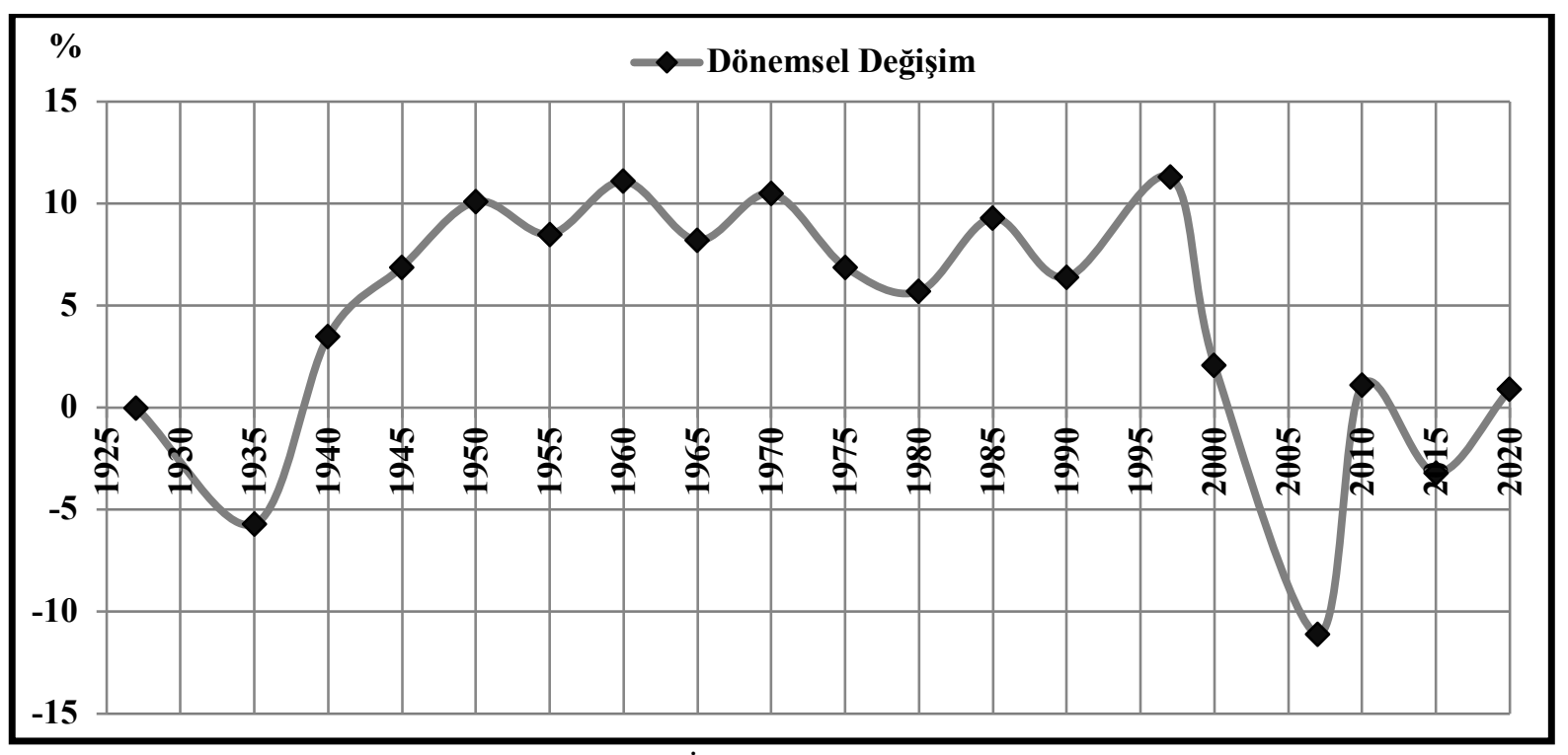

Şekil 1. Sayım Yıllarına Göre Kütahya İli Nüfusunun Dönemsel Değişim Oranlarını Gösterir Grafik $(1927-2020)$ 
Sahanın göç vermesi, sadece 1997 yılı ve sonrasında yaşanan bir süreç de değildir. Nitekim sayım yıllarına göre ilin; aldığı, verdiği ve net göçleri gösteren tablo (Tablo 2) ve şekilde (Şekil 2) de görüleceği üzere bu sürecin geçmişi daha eskilere kadar uzanmaktadır. Zira ilgili tabloya göre Kütahya ili; 1985-1990 döneminden başlayarak 1995-2000, 2007-2010, 2010-2015 ve 2015-2020 dönemlerinde de göç vermiştir. Ancak özellikle 2007 ilâ 2010 yılları arasında geçen 3 yıllık süreçte ilin net göçlerinde, 15.130 kişilik tarihsel bir açık meydana gelmiştir. Daha sonraysa bunu bir sonraki dönem olan 2010-2015 yılları arasında geçen 5 yıllık sürede net göçlerde verilen 8.316 kişilik açık takip etmiştir.

Tablo 2. Sayım Yıllarına Göre Kütahya İlinin; Aldığı, Verdiği ve Net Göç Tablosu (1975-2020) ${ }^{1}$

\begin{tabular}{|c|c|c|c||}
\hline Yıl & Aldı̆̆ı Göç & Verdiği Göç & Net Göç \\
\hline $1975-1980$ & 22.640 & 22.257 & 383 \\
\hline $1980-1985$ & 23.390 & 23.353 & 37 \\
\hline $1985-1990$ & 26.327 & 30.936 & -4.609 \\
\hline $1990-1995^{*}$ & - & - & -1.064 \\
\hline $1995-2000$ & 38.553 & 39.617 & - \\
\hline $2000-2007^{*}$ & - & - & -15.130 \\
\hline $2007-2010$ & 44.714 & 59.844 & -8.316 \\
\hline $2010-2015$ & 94.153 & 102.469 & -6.925 \\
\hline $2015-2020$ & 94.695 & 101.620 & -35.624 \\
\hline Toplam & 344.472 & 380.096 & - \\
\hline
\end{tabular}

Kaynak: TÜİK’in “Temel İstatistikler” veri tabanından yararlanılarak hazırlanmıştır.

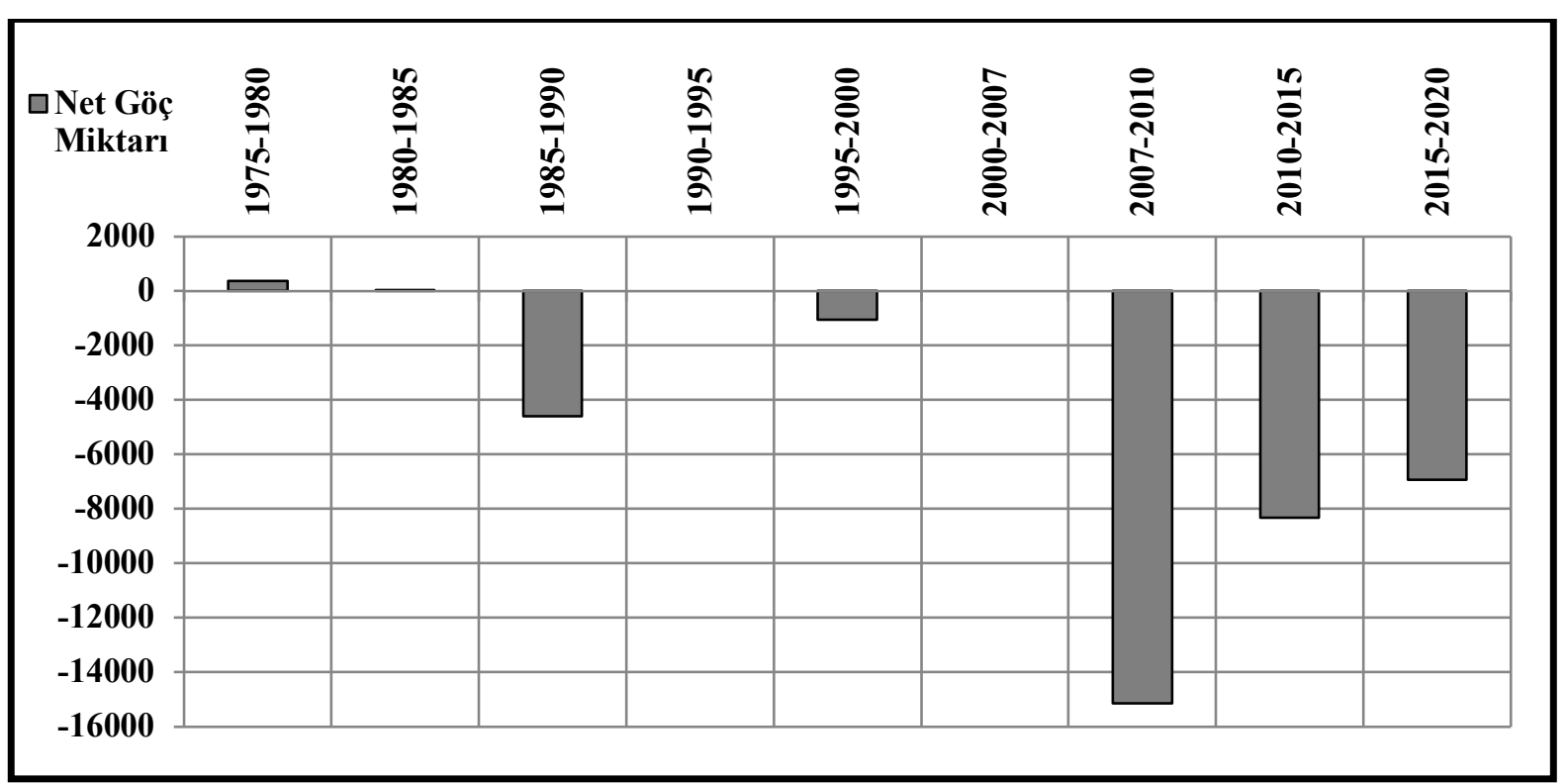

Şekil 2. Sayım Yıllarına Göre Kütahya İlinin Net Göç Miktarlarını Gösterir Grafik (1975-2020). ${ }^{2}$

1990-1995 yılları ve 2000-2007 yılları arasındaysa TÜİK'in veri tabanında bu konuyla ilgili herhangi bir kayda ulaşmak mümkün olmamıştır. Bu dönemlerde inceleme alanının göç verip vermediğiyle ilgili bir çıkarımda bulunabilmek için Tablo 1'deki Kütahya ilinin nüfus verilerine bakmak yerinde olacaktır. İlgili tabloya göre 1990-1995 yılları arasında olmasa da 1990 ilâ 1997 yılları arasındaki döneme ilişkin sahanın nüfus

1 1990-1995 yılları ile 2000-2007 yılları arasında TÜİ'in veri tabanında bu konuyla ilgili herhangi bir veri bulunmadığı için sözü edilen dönemler, hesaplamaya dâhil edilememiştir.

2 1990-1995 yılları ile 2000-2007 yılları arasında TÜİK'in veri tabanında bu konuyla ilgili herhangi bir veri bulunmadığı için sözü edilen dönemler, hesaplamaya dâhil edilememiştir. 
verileri bulunmaktadır. Buna göre 1990 yılında 578.020 kişi olan il nüfusunun 7 yıl sonra, \% 11,3 oranında artarak, 643.117 kişiye ulaştığı görülmektedir. Buradan belirtilen süreçte ilin göç aldığı çıkarımında bulunmak mümkündür. Ancak bunlardan ikincisi olan 2000 ilâ 2007 yılları arasında geçen 7 senelik süreçteyse il nüfusu 656.903 'ten, \% 11,1 oranında azalarak, 583.910 kişiye gerilemiştir. Bu da belirtilen süreçte sahanın dışarıya göç verdiğini göstermektedir.

Her ne kadar verilerde eksiklikler bulunsa da Tablo 2, araştırma sahasının göç geçmişi hakkında bir fikir vermektedir. Bu bilgiler sşığında bakıldığında bile Kütahya'nın ülkenin göç veren illerinden birisi olduğunu söylemek mümkündür. Nitekim 1975 ilâ 2020 yılları arasında ilin aldığı ve verdiği göçler arasında 35.624 kişilik bir açık bulunmaktadır. Yine Tablo 2'deki yöntemle yapılan hesaplamayla sahanın Ege Bölgesi illeri içinde göç durumunu ortaya koyabilmek amaciyla Tablo 3 oluşturulmuştur. Buna göre inceleme alanı, Afyonkarahisar'dan sonra, bölgenin en fazla göç veren ikinci ilidir.

Tablo 3. Ege Bölgesi’nin Diğer İlleri ile Kütahya İlinin; Aldığı, Verdiği ve Net Göçler Açısından Karşılaştırma Tablosu $(1975-2020)^{3}$

\begin{tabular}{||l|c|c|c||}
\hline \multicolumn{1}{|c|}{ İlin Adı } & Aldığı Göç & Verdiği Göç & Net Göç \\
\hline Afyonkarahisar & 379.902 & 493.046 & -113.144 \\
\hline Kütahya & 344.472 & 380.096 & -35.624 \\
\hline Uşak & 197.087 & 202.445 & -5.358 \\
\hline Denizli & 490.988 & 448.754 & 42.234 \\
\hline Manisa & 720.123 & 669.830 & 50.293 \\
\hline Aydın & 704.252 & 577.967 & 126.285 \\
\hline Muğla & 677.323 & 501.196 & 176.127 \\
\hline İzmir & 2.521 .713 & 1.813 .223 & 708.490 \\
\hline
\end{tabular}

Kaynak: TÜİK' in "Temel İstatistikler” veri tabanından yararlanılarak hazırlanmıştır.

\section{Materyal ve Yöntem}

Kütahya ilinin özellikle 2000 yılı sonrasında iç göçlerdeki yerini ortaya koymayı amaçlayan çalışmaya ilk olarak literatür taramasıyla başlanmıştır. Bu kapsamda araştırma sahasıyla ilgili kullanılan istatistiki veriler; Devlet İstatistik Enstitüsü (DİE) tarafından yayımlanan Genel Nüfus Sayımı sonuçlarından ve TÜİK tarafından yayımlanan ADNKS veri tabanından alınmıştır. Yine bu kapsamda çalışma alanıyla ilgili hazırlanan; kitap, makale, tez, bildiri, rapor ve diğer kaynaklar temin edilmiştir.

Bunlardan TÜİK'in “Temel İstatistikler: İllerin Aldığı, Verdiği Göç, Net Göç ve Net Göç Hızı, Genel Nüfus Sayımları-ADNKS” veri tabanından yararlanılarak 1975-2020 yılları arasında sayım yıllarına göre araştırma sahasının; aldığı, verdiği ve net göç tablosu oluşturulmuştur. Ancak 1990-1995 yılları ile 2000-2007 yılları arasında TÜİK'in veri tabanında bu konuyla ilgili herhangi bir veri bulunmadığı için sözü edilen dönemler, hesaplamaya dâhil edilememiştir.

Gerek belirtilen yıllar arasındaki boşlukları doldurmak ve gerekse konuyu daha kapsamlı bir şekilde ele alabilmek için; DİE’nin Genel Nüfus Sayımı sonuçları ile TÜİK'in ADNKS veri tabanından yararlanılarak sayım yıllarına göre araştırma sahasının ve Türkiye nüfusunun karşılaştırıldığı bir tablo ve yine aynı veri kaynakları kullanılarak sayım yıllarına göre araştırma sahasının kırsal ve kentsel nüfus tablosu hazırlanmıştır.

Ayrıca TÜİK ADNKS'nin “İkamet Edilen İle Göre Nüfusa Kayıtlı Olunan İl” veri tabanından yararlanılarak "sahada ikamet edenlerin kayıtlı olduğu iller" saptanmıştır. Ardından yine TÜİK ADNKS'nin "Nüfusa Kayıtlı Olunan İle Göre İkamet Edilen İl”" veri tabanından yararlanılarak "araştırma sahası nüfusuna kayıtlı olanların yaşadığı iller" tespit edilmiştir. Son olarak da araştırma sahasında ikamet edip başka bir ilin nüfusuna kayıtlı olanlardan, araştırma sahası nüfusuna kayıtlı olup başka illerde yaşayan nüfus çıkarılarak aradaki fark bulunmuştur.

Ancak belirtilen farkın içinde; kendisi Kütahya ilinde doğduğu halde babası veya dedesi zamanında farklı bir ilden araştırma sahasına göç edip hâlâ geldikleri ilin nüfusuna kayıtlı olanlar bulunduğu gibi, dedesi veya babası zamanında inceleme alanından başka bir ile göç ettikten sonra orada doğan ve hâlâ Kütahya ili

3 1990-1995 yılları ile 2000-2007 yılları arasında TÜİK'in veri tabanında bu konuyla ilgili herhangi bir veri bulunmadığı için sözü edilen dönemler, hesaplamaya dâhil edilememiştir. 
nüfusuna kayıtlı olanlar da bulunmaktadır. Her ne kadar net göç sayısı kadar olmasa da bu durum, sahanın aldığı ve verdiği göç konusunda bir fikir vermektedir. Hatta bu durumun, geçmişte yaşanmış da olsa Cumhuriyet Dönemi’ndeki göçlerin inceleme alanıyla ilgili bölümündeki izlerinin sürülmesi ve sonuçlarının ortaya konulması açısından, çalışmaya katkı da sağladığı söylenebilir (Şahbaz, 2020: 110).

Nihayetinde de nicel araştırma ve sentez yönteminin yanı sıra beşeri coğrafya metodolojisi ile çalışmanın sonuçları ortaya konmuştur. Bu yapılırken de istatistiki verilere dayalı olarak oluşturulan tablolardan, bu tablolara dayalı olarak hazırlanan grafiklerden ve dağılış haritalarından istifade edilmiştir.

\section{Bulgular}

\section{1. Ülke İçinden Kütahya İline Yapılan Göçler}

Araştırma sahasının, yurt içinden aldığı göçleri ortaya koyabilmek amacıyla TÜİK’in "İkamet Edilen İle Göre Nüfusa Kayıtlı Olunan İl” veri tabanından yararlanılarak Tablo 4 oluşturulmuştur. Bu tabloya göre 31 Aralık 2020 tarihi itibarıyla Kütahya ilinde ikamet eden 88.377 kişi, ülkenin diğer illerine kayıtlıdır. Yine TÜİK verilerine göre sahada ikamet eden 479.061 kişi ise Kütahya ilinin nüfusuna kayıtlıdır. Bu durumda Kütahya ve Türkiye'nin diğer illerine kayıtlı olanların toplam sayısı 567.438 'dir.

Tablo 4. Kütahya İlinde İkamet Eden Nüfusun Kayıtlı Olduğu İllere Göre Dağılışını Gösterir Tablo (2020)

\begin{tabular}{|c|c|c|c|c|c|}
\hline İlin Adı & Kişi & İlin Adı & Kişi & İlin Adı & Kişi \\
\hline Afyonkarahisar & 10.837 & Hatay & 975 & Burdur & 454 \\
\hline Eskişehir & 6.398 & Çorum & 971 & Ardahan & 446 \\
\hline Bursa & 4.478 & Kayseri & 943 & Siirt & 435 \\
\hline Balıkesir & 4.098 & Kars & 908 & Kocaeli & 411 \\
\hline Manisa & 3.649 & Elazığ & 866 & Karaman & 405 \\
\hline Konya & 3.220 & Ağn1 & 863 & Sinop & 402 \\
\hline Uşak & 2.385 & Diyarbakır & 853 & Rize & 369 \\
\hline Bilecik & 2.362 & Şanlıurfa & 848 & Bolu & 364 \\
\hline Ankara & 1.904 & Antalya & 842 & Batman & 352 \\
\hline Erzurum & 1.817 & Gaziantep & 806 & Bitlis & 351 \\
\hline İzmir & 1.770 & Mardin & 770 & Nevşehir & 351 \\
\hline Van & 1.691 & Sakarya & 754 & Karabük & 348 \\
\hline Samsun & 1.486 & Kırıkkale & 681 & Kilis & 330 \\
\hline Sivas & 1.472 & Giresun & 627 & Gümüşhane & 256 \\
\hline Denizli & 1.409 & Kırşehir & 602 & Tekirdağ & 246 \\
\hline Trabzon & 1.274 & Adiyaman & 600 & Kırklareli & 245 \\
\hline Adana & 1.253 & Muş & 582 & Bayburt & 239 \\
\hline Niğde & 1.189 & Zonguldak & 544 & Bingöl & 235 \\
\hline Mersin & 1.131 & Aksaray & 532 & Bartın & 223 \\
\hline Tokat & 1.129 & Kastamonu & 520 & Düzce & 220 \\
\hline Malatya & 1.097 & Muğla & 515 & Edirne & 215 \\
\hline Kahramanmaraş & 1.072 & Amasya & 502 & Iğdır & 213 \\
\hline İstanbul & 1.038 & Osmaniye & 497 & Şırnak & 160 \\
\hline Yozgat & 1.032 & Çanakkale & 483 & Tunceli & 139 \\
\hline Ordu & 1.031 & Artvin & 482 & Hakkâri & 132 \\
\hline Aydin & 1.018 & Çankırı & 466 & Yalova & 109 \\
\hline Isparta & 996 & Erzincan & 459 & Toplam & 88.377 \\
\hline
\end{tabular}

Kaynak: TÜİK'in ADNKS “İkamet Edilen İle Göre Nüfusa Kayıtlı Olunan İl” veri tabanından yararlanılarak hesaplanmıştır.

Sayım yıllarına göre Kütahya ilinin nüfusunu gösteren Tablo 1'de de görüleceği üzere 31 Aralık 2020 tarihinde araştırma sahasında 576.688 kişi yaşamaktaydı. Bu durumda belirtilen tarihteki ilin toplam nüfusundan Türkiye'nin diğer illerinin nüfusuna kayıtlı olanlar çıkarıldığı takdirde, 9.250 kişilik bir fark ortaya çıkmaktadır. Bunların da Türkiye nüfusuna kayıtlı olmayanlar, dolayısıyla yabancılar, olduğu anlaşılmaktadır. Muhtemelen 
bunlar; başta Suriyeliler olmak üzere, Irak, Afganistan ve İran'dan gelenlerdir. Bunlar hariç tutulursa araştırma alanındaki nüfusun \% 18,4'ünün il nüfusuna kayıtlı olmayanların, dolayısıyla ülkenin diğer illerinden gelenlerin, oluşturduğu sonucuna ulaşmak mümkündür.

En fazla göç aldığı iller açısından sahaya bakıldığında, 10.837 kişi ile Afyonkarahisar ili nüfusuna kayıtlı olanların başı çektiği görülmektedir. Bu ili Eskişehir (6.398 kişi), Bursa (4.478 kişi), Balıkesir (4.098 kişi), Manisa (3.649 kişi), Konya (3.220 kişi), Uşak (2.385 kişi) ve Bilecik (2.362 kişi) takip etmektedir. Harita 2 'de de görüleceği üzere Konya hariç sözü edilen illerin tümünün Kütahya iliyle komşu olması, sahanın en çok göçü yakın çevresinden fonksiyonel etkisi nedeniyle aldığını göstermektedir. Öyle ki sahanın çevresindeki 7 komşu ilden aldığı göçün oranı, toplam aldığı göçün \% 37,8'ine tekabül etmektedir.

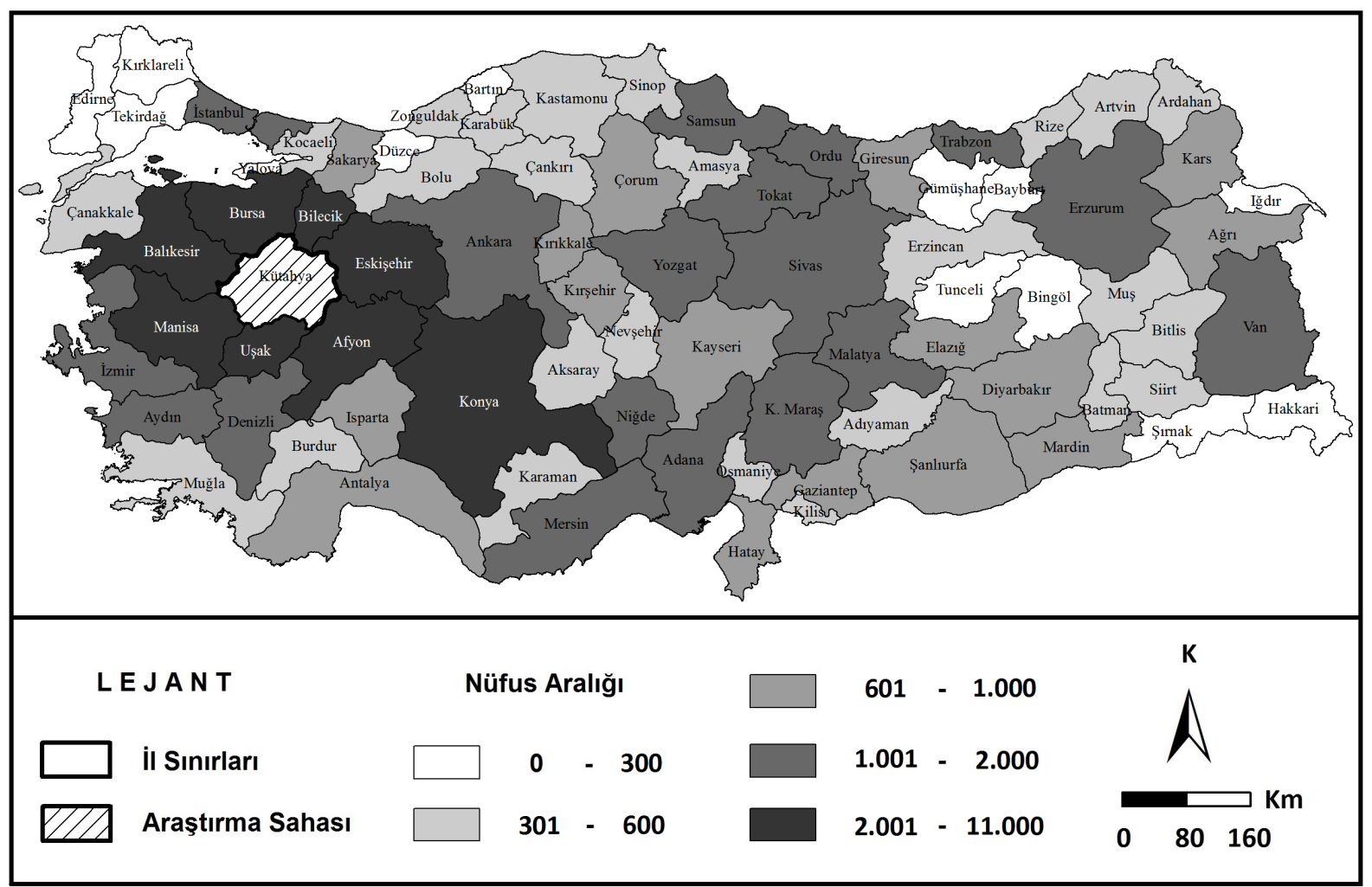

Harita 2. Kütahya İlinde İkamet Eden Nüfusun Kayıtlı Olduğu İllere Göre Dağılışını Gösterir Harita (2020)

Araştırma sahasına en fazla göç veren il olan Afyonkarahisar'ın durumuna bakıldığında, doğurganlık oranının yüksek ve ekonomisinin de büyük ölçüde tarım ve hayvancılığa dayalı olduğu görülmektedir (Yakar vd., 2010: 260). Ancak burada dikkati çeken bir diğer husus, araştırma sahasında ikamet ettiği halde Afyonkarahisar ili nüfusuna kayıtlı olanların büyük bir kısmının Kütahya ilinin merkez ilçesine sınır komşusu olan İhsaniye ilçesinden gelmiş olmasıdır. Nitekim TÜİK ADNKS verilerine göre 31 Aralık 2020 tarihi itibarıyla Kütahya'da ikamet eden 10.837 Afyonkarahisar ili nüfusuna kayıtlı olanların \% 47,5'ini (5.145 kişi) İhsaniye ilçesi nüfusuna kayıtlı olanlar oluşturmaktadır.

Kütahya'ya en çok göç veren ikinci il olan Eskişehir, ülke içinde göçe katılan nüfus açısından önemli bir çekim merkezidir. Nitekim bu ile yönelik göçlerin ana hedefi olan Eskişehir kenti; gelişmiş sanayi ve ticaretiyle ekonomik sıkıntıda olanlar için iş umudu; eğitim, kültür, sağlık ve sosyal faaliyet merkezleri ile de yaşam kalitesini artırmak isteyenler için cazibe merkezidir (Şahbaz, 2020: 121). Dolayısıyla bu ilden araştırma sahasına yapılan göçlerin nedeninin sosyo-ekonomik değil, eğitim ya da tayin/atama gibi gerekçelerle gerçekleştirildiğini söylemek mümkündür.

Bundan başka Kütahya'da ikamet eden ve Eskişehir nüfusuna kayıtlı olanların bu ilin daha çok neresinden geldiğine bakıldığındaysa, bunların büyük bir kısmının 2008 yılına kadar Eskişehir ilinin merkez ilçesi konumunda olan ve daha sonrasındaysa ikiye bölünerek, Odunpazarı ve Tepebaşı adını alan ilçelerin nüfusuna kayıtlı oldukları görülmektedir. Nitekim TÜIKK ADNKS verilerine göre 31 Aralık 2020 tarihi itibarıyla Kütahya'da ikamet eden 6.398 Eskişehir ili nüfusuna kayıtlı olanların \% 41,8'ini (2.676 kişi) bu ilçelerin 
nüfusuna kayıtlı olanlar oluşturmaktadır. Bunları \% 9,6 (613 kişi) ile Seyitgazi ilçesi nüfusuna kayıtlı olanlar takip etmektedir.

İnceleme alanının en çok göç aldığı üçüncü il olan Bursa'nın durumuna bakıldığında; binek tipi otomobil, minibüs, kamyon ve kamyonet üretimi açısından onun ülkede önemli bir merkez olduğu görülmektedir. Bursa'nın hem üretim hem de istihdam açısından ön plana çıktığı bir diğer sektörse, tekstildir. Bundan başka ilde ve özellikle İnegöl ilçesinde mobilya sektörü de oldukça gelişmiştir (Çavuş vd., 2013). Bunların bir sonucu olarak il, ülke genelinde göçe katılan nüfus açısından önemli bir çekim merkezidir. Dolayısıyla bu ilden araştırma sahasına yapılan göçlerin de eğitim ya da tayin/atama gibi gerekçelerle gerçekleştirildiğini söylemek mümkündür.

Ancak araştırma sahasında ikamet ettiği halde Bursa nüfusuna kayıtlı olanların bu ilin daha çok neresinden geldiğine bakıldığındaysa, onların büyük bir kısmının Kütahya ili ile sınır komşusu olan; Harmancık, İnegöl ve Keles ilçelerinin nüfusuna kayıtlı oldukları görülmektedir. Nitekim TÜIKK ADNKS verilerine göre 31 Aralık 2020 tarihi itibarıla inceleme alanında ikamet eden 4.478 Bursa ili nüfusuna kayıtlı kişinin \% 43,4'ü (2.163 kişi) bu ilçelerden gelmiştir.

Sahaya en çok göç veren dördüncü il, Balıkesir'dir. TÜIK ADNKS verilerine göre 31 Aralık 2020 tarihi itibarılla inceleme alanında ikamet ettiği halde Balıkesir nüfusuna kayıtlı olan 4.098 kişinin bu ilin daha çok neresinden geldiğine bakıldığındaysa, bunların da büyük bir kısmının $(\%$ 50,9) Kütahya ili ile sınır komşusu olan Dursunbey ve Sındırgı ilçelerinin nüfusuna kayıtlı olduğu görülmektedir.

İnceleme alanının en çok göç aldığı beşinci il olan Manisa'da Vestel City, Bosch, Klimasan ve Mitsubishi Electric gibi büyük firmaların sanayi yatırımları bulunmaktadır. Bundan başka Manisa, İzmir'den sonra, Ege Bölgesi'nin en fazla ihracat yapan ikinci ilidir. Dahası Manisa; İzmir Limanı'na yakınlığı, önemli demiryolu ve karayolu arterlerinin geçiş noktasında bulunması, kalifiye işçi temin edilebilmesi gibi hususlar nedeniyle, 2005 yılında Avrupa kentleri arasında "Doğrudan Yabancı Yatırım İçin En Uygun Şehir" seçilmiştir (Aktaş ve Karğın, 2019: 1-14). Dolayısıyla bu ilden araştırma sahasına yapılan göçlerin nedeninin de daha çok tayin/atama ya da eğitim gibi gerekçelerle yapıldığını söylemek mümkündür.

Bundan başka araştırma sahasında ikamet ettiği halde Manisa nüfusuna kayıtlı olanların bu ilin daha çok neresinden geldiğine bakıldığındaysa, onların büyük bir kısmının Kütahya ili ile sınır komşusu olan; Demirci ilçesinin nüfusuna kayıtll olduğu görülmektedir. Gerçekten TÜIK ADNKS verilerine göre 31 Aralık 2020 tarihi itibarıla Kütahya'da ikamet eden 4.098 Manisa ili nüfusuna kayıtlı olanların \% 30'unu (1.094 kişi) bu ilçenin nüfusuna kayıtlı olanlar oluşturmaktadır. Bunun nedenlerine bakıldığında; Demirci ilçesinin özellikle Kütahya ili sınırındaki kırsal yerleşmelerinde yaşayan halkın geçim kaynağının daha çok tarım ve hayvancılığa dayandığı, buna karşın sözü edilen yerlerdeki ana kayanın toprağın gelişimini engellemesi yüzünden toprak kalınlığının 0-30 cm arasında değiştiği, dahası topoğrafya şartları bozuk olduğu için tarlaların eğimli ve küçük parçalar halinde ve sulama imkânının da yok denecek kadar az olduğu görülmektedir. Buna bağlı olarak burada yaşayan insanlar, geçim kaygısı taşımakta (Aydın, 2004: 249) ve bu da sözü edilen ilçeden dışarıya göçlere sebep olmaktadır.

Kütahya'ya en çok göç veren altıncı il, Konya'dır. Karasal iklim şartlarının etkili olduğu Konya Ovası, aynı zamanda Türkiye'nin en az yağış alan bölümüdür. Büyük çapta bir akarsuyun da olmadığı il topraklarının büyük bir kısmında tarla bitkileri yetiştiriciliği yapılmaktadır. Bunlara bağlı olarak Konya Ovası'nda; erozyon, sulama, toprak sığlı̆̆ı, drenaj sorunu, tuzluluk ve alkalilik gibi toprak sorunları vardır (Bozyiğit ve Güngör, 2011: 197). Tüm bunlar da söz konusu ilin kırsal kesiminden göçlere sebep olmaktadır.

Araştırma sahasına en çok göç veren yedinci il, Uşak'tır. Kütahya'da ikamet ettiği halde Ușak nüfusuna kayıtlı olanların bu ilin daha çok neresinden geldiklerine bakıldığındaysa, bunların büyük bir kısmının araştırma sahası ile sınır komşusu olan; merkez ilçe ve Banaz nüfusuna kayıtlı oldukları görülmektedir. Nitekim TÜiK ADNKS verilerine göre 31 Aralık 2020 tarihi itibarıyla Kütahya'da ikamet eden 2.385 Uşak ili nüfusuna kayıtlı kişinin \% 65,8'ini (1.570 kişi) bu ilçelerin nüfusuna kayıtlı olanlar oluşturmaktadır.

İnceleme alanının en çok göç aldığı sekizinci il olan Bilecik'in durumuna bakıldığında ülkenin en küçük illerinden birisi olması nedeniyle de Bilecik'teki; ticari, sosyal ve kültürel faaliyetlerin yeterince gelişme imkânı bulamadığı görülmektedir. İstihdama olumsuz bir şekilde yansıyan bu nedenler de Bileciklilerin memleketlerinden başka yerlere göçüne sebep olmaktadır. Nitekim bunlardan bir kısmı da Kütahya ilini tercih etmiştir. Ancak araştırma sahasında ikamet ettiği halde Bilecik nüfusuna kayıtlı olanların bu ilin daha çok neresinden geldiğgine bakıldığındaysa, bunların büyük bir kısmının Kütahya ilinin merkez ilçesi ile sınır komşusu olan Bozüyük ilçesinin nüfusuna kayıtlı olduğu görülmektedir. Gerçekten 31 Aralık 2020 tarihi itibarılyla Kütahya'da ikamet eden 2.385 Bileciklinin \% 54,6’sı, bu ilçenin nüfusuna kayıtlıdır. 
Bozüyük şehrinde sanayinin oldukça geliştiği ve buna bağlı olarak da bu sektörde çalışan nüfus oranının yüksek olduğu (Özgür, 1994: 188-189) göz önünde bulundurulursa, bu ilçeden sahaya yapılan göçlerin daha çok Kütahya şehrinin fonksiyonel etki sahası altında kalan kırsal yerleşmelerden ve eğitim ya da tayin/atama gibi gerekçelerle gerçekleştirildiğini söylemek mümkündür.

Araştırma sahası, yukarıda bahsi geçen illerden başka az veya çok ülkenin diğer vilayetlerinden ve dolayısıyla da coğrafi bölgelerinden göç almıştır. Göçlerin bölgelere göre dağılışına bakıldı̆̆ında; Ege, İç Anadolu ve Marmara bölgelerinin kesişim noktasında bulunan ilin en çok göçü bu bölgelerden aldığ görülmektedir (Tablo 5, Şekil 3). Bunları; Karadeniz, Doğu Anadolu, Akdeniz ve Güneydoğu Anadolu bölgeleri takip etmektedir.

Tablo 5. Kütahya İlinde İkamet Eden Nüfusun Kayıtlı Olduğu Coğrafi Bölgelere Göre Dağılışını Gösterir Tablo (2020)

\begin{tabular}{||l|c|c||}
\hline \multicolumn{1}{|c|}{ Bölgenin Adı } & Kişi & \%'si \\
\hline Ege & 21.583 & 24,4 \\
\hline İç Anadolu & 19.195 & 21,7 \\
\hline Marmara & 14.439 & 16,3 \\
\hline Karadeniz & 10.987 & 12,4 \\
\hline Doğu Anadolu & 9.959 & 11,3 \\
\hline Akdeniz & 7.220 & 8,2 \\
\hline Güneydoğu Anadolu & 4.994 & 5,7 \\
\hline Toplam & $\mathbf{8 8 . 3 7 7}$ & $\mathbf{1 0 0 , 0}$ \\
\hline
\end{tabular}

Kaynak: Tablo 4’ten yararlanılarak hesaplanmıștır.

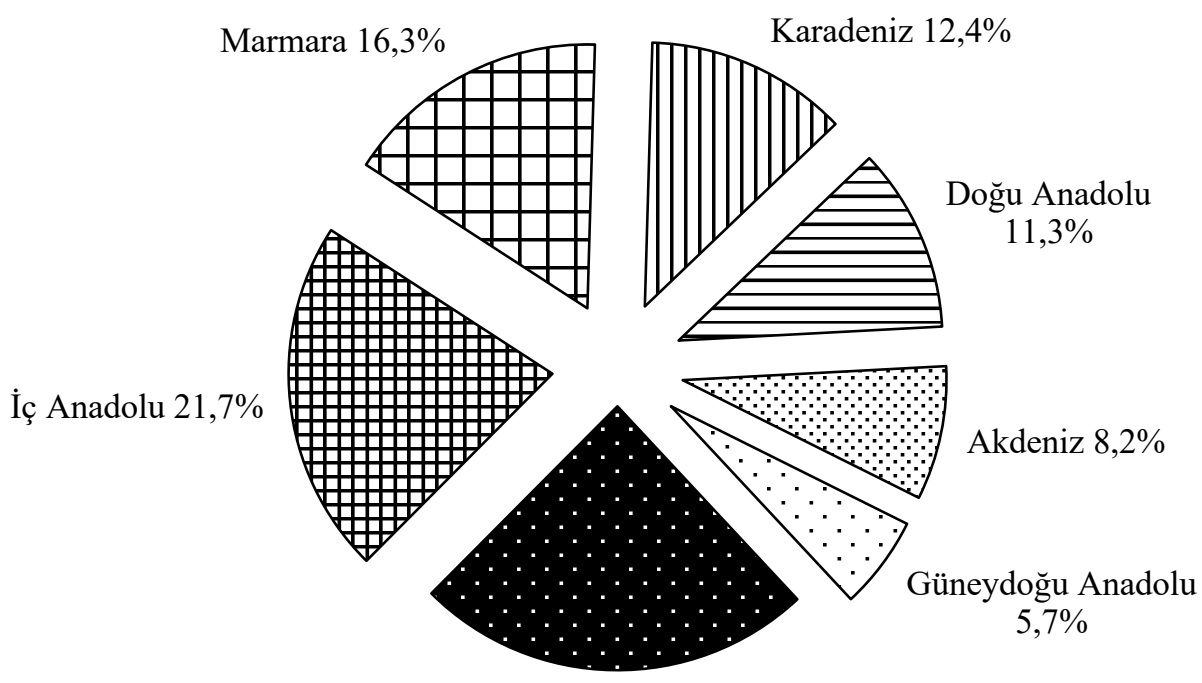

Ege $24,4 \%$

Şekil 3. Kütahya İlinde İkamet Eden Nüfusun Kayıtlı Olduğu Coğrafi Bölgelere Göre Dağılışını Gösterir Pasta Grafik (2020)

Kütahya ilinin ülke içinden aldığı göçlerin \% 24,4’ü (21.583 kişi), Ege Bölgesi’nden kaynaklanmaktadır. Bununsa \% 50,2'sini Afyonkarahisar ili nüfusuna kayıtlı olanlar oluşturmaktadır. \% 16,9 oranıyla Manisa ve \% 11,1 oranıyla da Uşak, bu bölgeden sahaya göç gönderen diğer illerdir.

İnceleme alanının ülke içinden aldığı göçlerin \% 21,7’si (19.195 kişi) ise İç Anadolu Bölgesi kaynaklıdır. Bununsa \% 33,3'ünü Eskişehir ili nüfusuna kayıtlı olanlar oluşturmaktadır. Bu ili ise \% 16,8 oranıla Konya ili takip etmektedir.

Araştırma sahasının ülke içinden aldığı göçlerin \% 16,3’ü (14.439 kişi) ise Marmara Bölgesi’nden kaynaklanmaktadır. Bunun \% 31'ini Bursa ili nüfusuna kayıtlı olanlar oluşturmaktadır. Bu ili \% 28,4 oranıyla Balıkesir ve \% 16,4 oranıyla da Bilecik illeri takip etmektedir. Buraya kadar adı geçen illerin araştırma sahasına neden bu denli göç verdiğine yukarıda değinilmişti. 
Kütahya ilinde ikamet eden Karadeniz Bölgesi nüfusuna kayıtlı olanlar ise \% 12,4'lük (10.987 kişi) bir paya sahiptir. Bununsa \% 31'i Samsun ilinden kaynaklanmaktadır. Bu ili \% 11,6 oranıla Trabzon ve \% 10,3 oranıla da Tokat illeri takip etmektedir. Adı geçen illerden Karadeniz Bölgesi'nin en büyük kenti olan Samsun'un durumuna bakıldığında; onun özellikle 1950'li yıllardan itibaren doğusundaki illerden yoğun bir şekilde göç aldığı, ancak 1970'li yılların ikinci yarısından itibaren bu ildeki ekonomik gelişmenin durması ve hatta gerilemeye başlamasıyla bu göçlerin asgari düzeye indiği görülmektedir. Bu gerilemeye bağlı olarak Samsun ili de batı illerine göç vermeye başlamış (Yılmaz ve Zeybek, 2016, 171-173) ve bu yaşananlardan inceleme alanı da etkilenmiştir.

Araştırma sahasına Karadeniz Bölgesi’nden ikinci en çok göç veren il, Doğu Karadeniz Bölümü’nde yer alan, Trabzon'dur. Nüfus yoğunluğunun yüksek olduğu Trabzon, gerek arazisinin büyük bir bölümünün tarıma elverişli olmaması ve gerekse nüfus artışının hızlı olması nedeniyle, göç olayının eskiden beri önem kazandığı bir il olmuştur (Doğanay, 1986: 281). Nitekim nüfus artış hızına bağlı olarak düşürülemeyen işsizlik oranları, özellikle Trabzon'un kırsal kesimden göçlere sebep olmaktadır (Şen, 2014: 60).

Karadeniz Bölgesi'nden sahaya en çok göç veren üçüncü il, Tokat'tır. Tarımdan sanayiye yeterince dönüşüm yapılamaması nedeniyle bu il, hem GSYH (toplam ve kişi başına), hem de sosyo-ekonomik gelişmişlik göstergeler açısından bölge ve ülke ortalamasının oldukça gerisinde yer almaktadır. Bu durum işsizliğin artmasına ve özellikle 2000'li yıllardan itibaren ilin sürekli göç vermesine sebep olmuştur (Barış, 2019: 123).

İnceleme alanının ülke içinden aldığı göçlerin \% 11,3’ünü (9.959 kişi) ise Doğu Anadolu Bölgesi’nden yapılan göçler oluşturmaktadır. Bunun da \% 18,2'si Erzurum'dan ve \% 17'si de Van ilinden kaynaklanmaktadır. Bunlardan Erzurumluları il dışı göçe zorlayan nedenler arasında; iklim şartlarının çetin olması, yüksek yakacak harcamaları, tarım olanaklarının azlığı, geçimin daha çok küçük aile işletmesi şeklindeki hayvancılığa dayanması, doğum oranının yüksek olması ve buna karşın istihdam sağlayacak büyük sanayi kuruluşlarının olmaması gösterilebilir (Yavuz, 1993: 17-18). Bunlardan başka sosyo-ekonomik imkânların kısıtlılığı ve coğrafi konumun getirdiği dezavantajlar da Erzurum şehrinden göçe sebep olan diğer faktörlerdir (Küçükali, 2018: 605).

Van ilinden yapılan göçlerdeyse, demografik yapının önemli bir rolü vardır. Nitekim il nüfusunun yaklaşık yarısı kırsalda yaşamaktadır ve ildeki doğurganlık hızı da Türkiye ortalamasının oldukça üzerindedir. $\mathrm{Bu}$ durum, nüfus miktarını artırmakta ve var olan zayıf ekonomik kaynaklar üzerindeki baskıyı artırarak ilden göçü hızlandırmaktadır. Bundan başka ilde hane başına düşen fert sayısının hem bölge ve hem de ülke ortalamasının üzerinde olması da Van'dan göçün önemli bir sebebidir. Van ilinde nüfus hareketliliğine etki eden faktörlerden bir diğeri de siyasal olaylardır. Özellikle 1980'li yıllardan sonra bölgede etkili olan bu olaylar, köyden kente ve kentten de diğer kentlere bir göç dalgasının yaşanmasına sebep olmuştur. Çatışmalı ortamdan kaynaklanan zorunlu göçler, özellikle kırsal alandaki nüfusu olumsuz bir şekilde etkilemiştir. Çünkü geçimini tarımsal faaliyetlerden sağlayan kırsal nüfus, ekonomik faaliyetlerini yerine getiremediği için bulunduğu yeri terk etmek zorunda kalmıştır (Elmastaş ve Yılmaz, 2015: 403).

Kütahya iline yukarıda adı geçen bölgelerden başka \% 8,2 oranıla Akdeniz Bölgesi'nden ve \% 5,7 oranıyla Güneydoğu Anadolu Bölgesi’nden göçler de olmuştur. Akdeniz Bölgesi’nden yapılan göçlerin \% 17,4’ü Adana ilinden kaynaklanmaktadır. Bu ili Mersin (\% 15,7) ve Kahramanmaraş (\% 14,8) illeri takip etmektedir. Güneydoğu Anadolu Bölgesi'nden yapılan göçlerinse \% 17,1'i Diyarbakır, \% 17'si ise Şanlıurfa ilinden kaynaklanmaktadır. Bunlardan Güneydoğu Anadolu'dan yapılan göçler, bölgedeki doğurganlık oranının Türkiye'nin gelişmiş bölgelerindekinin iki katından fazla olmasıyla açıklanabilir. Zira doğurganlık oranının yüksek olması nüfus artışına, nüfus artışı da işsizliğe ve göçe sebep olmaktadır. Bölge dışına göç hareketinin yüksek olmasının nedenlerinden bir diğeri de bölgedeki silahlı çatışmalar nedeniyle 1990-1995 yılları arasında ortaya çıkan zorunlu göç olgusudur (Erkan ve Aydın, 2010: 44).

\subsection{Kütahya İlinden Ülke İçine Yapılan Göçler}

İnceleme alanından ülkenin farklı yerlerine yapılan göçlerle ilgili durumu ortaya koyabilmek için, TÜİK' in Nüfusa Kayıtlı Olunan İle Göre İkamet Edilen İl veri tabanından istifade edilmiştir. 31 Aralık 2020 tarihi itibarıyla saha nüfusuna kayıtlı olanların yaşadığı illeri gösteren Tablo 6 ve Harita 3 incelendiğinde, bu göçlerin hedefinde; İzmir, İstanbul, Bursa, Manisa, Uşak, Eskişehir, Ankara ve Antalya illerinin olduğu görülmektedir. Sahanın bu 8 ile verdiği göç, toplam verdiği göçün \% 78,8'ine tekabül etmektedir.

Araştırma sahasının en çok göç verdiği il olan İzmir'in durumuna bakıldığında onun; coğrafi konumu, doğal kaynakları, tarihsel alt yapısı, kültürel zenginlikleri ve insan gücü açısından Türkiye'de ve dünyada öne çıkan bir il olduğu görülmektedir. Ulusal ve uluslararası taşımacılık açısından önemli bir potansiyele sahip olan ilin, birden fazla limanı vardır. Ulaşım ve lojistik alt yapısı ile ekonomik faaliyetler açısından çeşitliliği nedeniyle il, geçmişten günümüze önemli bir ticaret merkezi olmuştur. Zengin lojistik alt yapısı ile Türkiye’nin 
batıya açılan önemli bir ticaret kapısı olan İzmir; sahip olduğu özellikler, yaşam standardı ve ekonomik potansiyeli ile yaşam için olduğu kadar yatırımcılar için de cazip bir ildir (Akgüngör vd., 2017: 13). Tüm bunlar da İzmir'in, gerek ülke genelinden ve gerekse Kütahya ilinden neden önemli ölçüde göç aldığını açıklamaktadır.

Tablo 6. Kütahya İli Nüfusuna Kayıtlı Olanların İkamet Ettikleri İllere Göre Dağılışını Gösterir Tablo (2020)

\begin{tabular}{|c|c|c|c|c|c|}
\hline İlin Adı & Kişi & İlin Adı & Kişi & İlin Adı & Kişi \\
\hline İzmir & 56.456 & Şanlıurfa & 523 & Çorum & 197 \\
\hline $\begin{array}{l}\text { İstanbul } \\
\text { Ins }\end{array}$ & 32.951 & Edirne & 513 & Yozgat & 197 \\
\hline Bursa & 28.269 & Zonguldak & 508 & Siirt & 190 \\
\hline Manisa & 23.733 & Kayseri & 491 & Bartın & 186 \\
\hline Uşak & 21.052 & Van & 482 & Tokat & 176 \\
\hline Eskişehir & 15.804 & Kurklareli & 480 & Amasya & 170 \\
\hline Ankara & 10.824 & Samsun & 469 & Bingöl & 168 \\
\hline Antalya & 10.108 & Şırnak & 468 & Bitlis & 168 \\
\hline Balıkesir & 5.843 & Düzce & 407 & Ordu & 168 \\
\hline Bilecik & 5.707 & Bolu & 401 & Tunceli & 167 \\
\hline Kocaeli & 4.902 & Erzurum & 386 & Nevşehir & 158 \\
\hline Afyonkarahisar & 3.726 & Mardin & 374 & Çankırı & 150 \\
\hline Muğla & 3.328 & Ağr1 & 313 & Karaman & 127 \\
\hline Aydın & 3.110 & Elazığ & 283 & Osmaniye & 123 \\
\hline Denizli & 2.386 & Malatya & 278 & Rize & 117 \\
\hline Konya & 1.769 & Kastamonu & 275 & Giresun & 115 \\
\hline Tekirdağ & 1.722 & Hakkâri & 274 & Iğdır & 101 \\
\hline Sakarya & 1.666 & Batman & 264 & Kırşehir & 100 \\
\hline Çanakkale & 1.331 & Erzincan & 257 & Niğde & 96 \\
\hline Isparta & 953 & Sivas & 257 & Bayburt & 91 \\
\hline Mersin & 716 & Kurıkkale & 235 & Gümüşhane & 86 \\
\hline Diyarbakır & 713 & Trabzon & 231 & Adiyaman & 77 \\
\hline Yalova & 713 & Kahramanmaraş & 224 & Artvin & 75 \\
\hline Hatay & 639 & Kars & 215 & Sinop & 73 \\
\hline Gaziantep & 616 & Karabük & 209 & Ardahan & 62 \\
\hline Adana & 530 & Muş & 205 & Kilis & 56 \\
\hline Burdur & 525 & Aksaray & 200 & Toplam & 252.708 \\
\hline
\end{tabular}

Kaynak: TÜİK ADNKS “Nüfusa Kayıtlı Olunan İle Göre İkamet Edilen İl” veri tabanından yararlanılarak hesaplanmıştır.

Saha nüfusuna kayıtlı olanların en fazla göç ettiği ikinci il, Asya ve Avrupa'nın kesişim noktasında yer alan ve Türkiye'nin gerek demografik ve gerekse ekonomik açıdan kalbi durumunda olan İstanbul'dur. Bu ilin göç almasının nedenleri arasında onun; eşsiz coğrafi konumu, tarihi ve mimari varlıkları, büyük altyapı yatırımları ve iki kıta ile olan ekonomik bağları gibi hususları sıralamak mümkündür. Bu faktörlerin birleşimi sayesinde İstanbul; endüstriyel, finansal ve lojistik açıdan ülkenin merkezi durumundadır. Tüm bunların bir sonucu olarak da il, 1950'li yıllardan itibaren dramatik bir nüfus artışına sahne olmuştur (OECD, 2008: 13).

İnceleme alanı nüfusuna kayıtlı olanların en fazla göç ettiği üçüncü il, Bursa'dır. Bu ilin ülke genelinde göçe katılan nüfus açısından önemli bir çekim merkezi olduğuna ve bunun nedenlerine daha önce değinilmişti. Bursa'da ikamet ettiği halde Kütahya nüfusuna kayıtlı olanların bu ilin daha çok neresinden gittiğine bakıldığındaysa, bunların büyük bir kısmının Domaniç ilçesinden kaynaklandığı görülmektedir. Nitekim TÜiK ADNKS verilerine göre 31 Aralık 2020 tarihi itibarıyla Bursa'da ikamet eden 23.733 Kütahya ili nüfusuna kayıtlı kişinin \% 41,1'i (11.605 kişi), bu ilçe nüfusuna kayıtlıdır. Bunu \% 23,7 (6.706 kişi) ile Tavşanlı ilçesi nüfusuna kayıtlı olanlar takip etmektedir. Bu ilçelerin Bursa ili ile sınır komşusu olması, onların ekonomik ve kültürel açıdan sözü edilen ilin fonksiyonel etki sahasında kaldıklarını göstermektedir.

Saha nüfusuna kayıtlı olanların en fazla göç ettiği dördüncü il Manisa'dır. Bu ilin de ülke genelinde göçe katılan nüfus açısından önemli bir çekim merkezi olduğuna ve bunun nedenlerine daha önce değinilmişti. 
Bunlara ilaveten sözü edilen ilde ikamet ettiği halde Kütahya nüfusuna kayıtlı olanların bu ilin daha çok neresinden gittiğine bakıldığındaysa, bunların büyük bir kısmının Manisa ili ile sınır komşusu olan Simav ilçesinden kaynaklandığı görülmektedir. Nitekim TÜİK ADNKS verilerine göre 31 Aralık 2020 tarihi itibarıyla Manisa'da ikamet eden 23.733 Kütahya ili nüfusuna kayıtlı kişinin \% 33,7'sini (8.008 kişi) bu ilçe nüfusuna kayıtlı olanlar oluşturmaktadır.

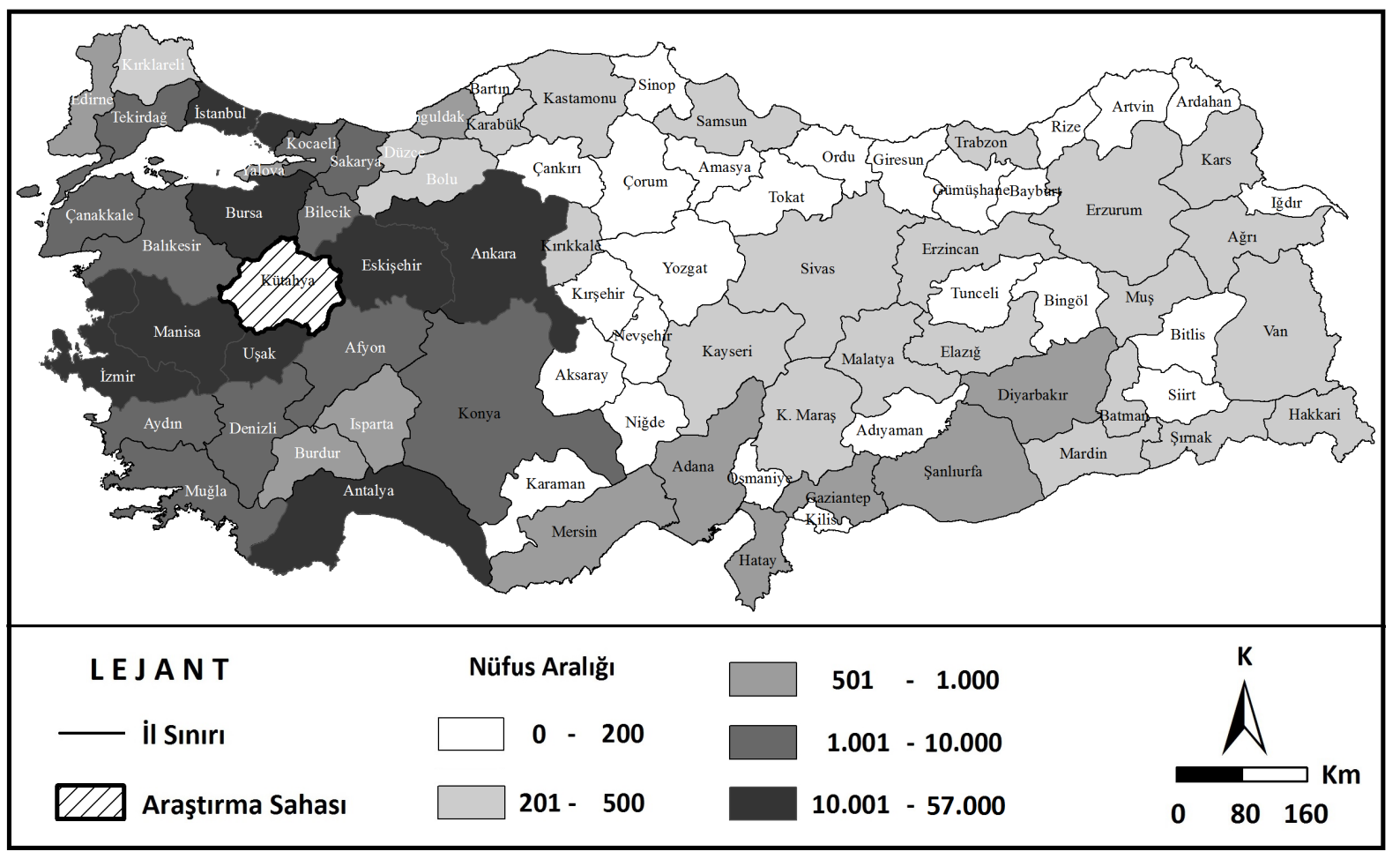

Harita 3. Kütahya İli Nüfusuna Kayıtlı Olanların İkamet Ettikleri İllere Göre Dağılışını Gösterir Harita (2020)

İnceleme alanı nüfusuna kayıtlı olanların en fazla göç ettiği beşinci il, Uşak’tır. Bunun nedenlerine bakıldığında; her ne kadar adı geçen kentteki gelişmişlik düzeyi yetersiz olsa da ve Uşak ilinin de sosyoekonomik açıdan yeterince gelişemediği görülse de bu ilin; tekstil, dericilik ve seramik sektörleri açısından ilerleme kaydettiği de bir gerçektir (Meçik vd., 2013: 60-67). Bundan başka söz konusu il, ulaşım açısından Anadolu içlerinden batıdaki büyük kentlere ve İzmir Limanı’na taşınan yük ve yolcular açısından da önemli bir güzergâh üzerinde bulunmaktadır (Deniz, 2014: 1). Ve bunlar da Kütahya ili nüfusuna kayıtlı olanların bir kısmının adı geçen ile göçü açısından yeterli olduğu anlaşılmaktadır.

Bundan başka Uşak’ta ikamet ettiği halde Kütahya nüfusuna kayıtlı olanların bu ilin daha çok neresinden olduğuna bakıldığındaysa, bunların büyük bir kısmının Gedizli olduğu görülmektedir. Nitekim TÜIK ADNKS verilerine göre 31 Aralık 2020 tarihi itibarıyla Uşak’ta ikamet eden 21.052 Kütahya ili nüfusuna kayıtlı kişinin \% 46,1'ini (9.699 kişi) Gediz ilçesinden olanlar oluşturmaktadır. Adı geçen ilçenin Uşak ilinin merkez ilçesi ile sınır komşusu olduğu göz önünde bulundurulursa onun, ekonomik ve kültürel açıdan Uşak şehrinin fonksiyon sahasında kaldığını söylemek mümkündür. Bundan başka \% 14,5 oranıyla Şaphane ve \% 14 oranıyla da Pazarlar ilçesinin nüfusuna kayıtlı olanlar da ikamet yeri olarak Uşak’ı tercih eden Kütahyalılardır.

Araştırma sahası nüfusuna kayıtlı olanların en fazla göç ettiği altıncı il, Eskişehir'dir. Bu ilin de ülke genelinde göçe katılan nüfus açısından önemli bir çekim merkezi olduğuna ve bunun nedenlerine daha önce değinilmişti. Bunlara ilaveten ülke içinde göçe katılan nüfusun söz konusu ili tercih etmesinde etkili olan hususlar arasında; Türkiye ve dünyaca ünlü markaların yanı sıra kamu iktisadi teşebbüsünün de imalat sanayi alanında Eskişehir ilinde önemli yatırımlarının bulunması vardır. Her biri bünyesinde önemli sayıda çalışan barındıran bu yatırımlara; Türkiye Lokomotif ve Motor Sanayi AȘ. (TÜLOMSAŞ), Ford Otosan İnönü Fabrikası, Türk Havacılık ve Uzay Sanayii AŞ. (TUSAŞ), Arçelik Buzdolabı Fabrikası, ETİ Gıda, Alp Havacılık, Eskișehir Şeker Fabrikası, CCS-Sarar, Çetintaş, Şișecam/Paşabahçe Fabrikası, Anadolu Cam Fabrikası, GKN Driveline ve Candy Hoover Group’u örnek olarak göstermek mümkündür (Şahbaz, 2020: 118).

Bundan başka Eskişehir'de ikamet ettiği halde Kütahya nüfusuna kayıtlı olanların bu ilin daha çok neresinden gittiğine bakıldığındaysa, bunların büyük bir kısmının Kütahya merkez ilçesinin nüfusuna kayıtlı 
olduğu görülmektedir. Nitekim TÜiK ADNKS verilerine göre 31 Aralık 2020 tarihi itibarıyla Eskişehir'de ikamet eden 15.804 Kütahya ili nüfusuna kayıtlı olanların \% 62,8'ini (9.920 kişi) bu ilçe nüfusuna kayıtlı olanlar oluşturmaktadır. Kütahya merkez ilçesi ise 2008 yılında büyükşehir oluncaya kadar Eskişehir ilinin merkez ilçesi konumunda olan ve daha sonrasındaysa ikiye bölünerek, Odunpazarı ve Tepebaşı adını alan ilçelerle sınır komşusudur. Aynı zamanda bu iki ilçe, Eskişehir kentini de bünyesinde barındırmaktadır. Buradan hareketle Kütahya merkez ilçesinin, Eskişehir kentinin ekonomik ve kültürel fonksiyon sahasından etkilendiği çıkarımında bulunmak mümkündür.

Saha nüfusuna kayıtlı olanların en fazla göç ettiği yedinci il, Ankara'dır. 1923 yılında Türkiye Cumhuriyeti'nin başkenti ilan edilmesiyle hızlı bir gelişme sürecine giren Ankara, başta kamu hizmetleri alanında olmak üzere çok sayıda hizmet sektörü işkolunda ülkesel ölçekte önemli bir merkez haline gelmiş ve ülkenin ikinci büyük kenti olmuştur (Özaslan, 2011: 337). Bundan başka yüksek teknolojili ürün üreten sanayisinin yanı sıra il, sahip olduğu çok sayıdaki yükseköğretim kurumu ile de eğitim açısından ülkenin önde gelen illerinden biridir (Ankara Kalkınma Ajansı, 2018: 4-5). Tüm bunların bir sonucu olarak il, ülke genelinden olduğu gibi araştırma sahasından da göç almıştır.

Çalışma alanı nüfusuna kayıtlı olanların en fazla göç ettiği sekizinci il, ekonomisinde turizm sektörünün çok önemli bir yeri olan Antalya'dır. Bu sektör, aynı zamanda Antalya'daki birçok alandaki üretimi de harekete geçirmektedir. Nitekim otel, lokanta, havaalanı, ulaştırma ve destek hizmetlerine bağlı olarak ilde; mobilya, otel tekstili, yiyecek-içecek üretimi, temizlik, özel güvenlik ve çevre düzenlemesi gibi faaliyetler de önem kazanmıştır (Toksöz, 2011: 3). Bundan başka topoğrafik yapısı ve iklim özellikleri nedeniyle Antalya ilindeki tarım alanlarının ve bitkisel üretim değerlerinin, ülkede çok önemli bir yeri de vardır (Ulukapı ve Şener, 2017: 271). Bunlara bağlı olarak söz konusu il, ülke genelinden olduğu gibi Kütahya’dan da göç almıştır.

İnceleme alanı nüfusuna kayıtlı olanların en fazla ikamet ettiği dokuzuncu il olan Balıkesir'in durumuna bakıldığında, onun sosyo-ekonomik gelişme düzeyinin Türkiye ortalamasının üzerinde olduğu görülmektedir. Tarım sektörünün ağırlığı nedeniyle tarıma dayalı sanayinin geliştiği bu ilin ekonomisinde turizmin de önemli bir yeri vardır (Aydemir, 2005: 131). Zira il, Ege ve Marmara Denizi'nde toplam 290,5 km'lik kıyı bandına sahiptir (Karaman vd., 2019: 5).

Araştırma sahasının en çok göç verdiği onuncu il olan Bilecik'in göç veren bir yer olduğuna ve bunun da nedenlerine daha önce değinilmişti. Bunlara ilaveten Bilecik’te ikamet ettiği halde Kütahya ili nüfusuna kayıtlı olanların araştırma sahasının daha çok neresinden geldiğine bakıldığındaysa, onların büyük bir kısmının merkez ilçeden olduğu görülmektedir. Nitekim TÜIKK ADNKS verilerine göre 31 Aralık 2020 tarihi itibarıly Bilecik ilinde ikamet eden 5.707 inceleme alanı nüfusuna kayıtlı kişinin \% 59,1'ini (3.371 kişi) bu ilçe nüfusuna kayıtlı olanlar oluşturmaktadır. Kütahya ili nüfusuna kayıtlı olanların Bilecik ilinin daha çok neresinde ikamet ettiğine bakıldığındaysa, onların \% 72'sinin (4.107 kişi) Bozüyük ilçesinde yaşadığı görülmektedir. Kütahya ilinin merkez ilçesi ile sınır komşusu olan bu ilçenin merkezi durumunda bulunan Bozüyük şehri, aynı zamanda sanayinin de oldukça geliştiği bir yerdir.

Saha nüfusuna kayıtlı olanların en çok ikamet ettiği on birinci il, Kocaeli'dir. Göçe katılan nüfus açısından bu ili cazip kılan nedense, onun; Avrupa'yı Anadolu'ya bağlayan önemli kara, deniz ve demiryolu ulaşım ağlarının merkezinde bulunması; Bursa, İstanbul gibi önemli merkezlere yakınlığı nedeniyle ara malı ve yatırım malı üreten imalat sanayi alanında ilde büyük yatırımların bulunmasıdır (Mert vd., 2005: 43).

Kütahya nüfusuna kayıtlı olanların yerleşmek için en çok tercih ettĭgi bir diğer il de Afyonkarahisar'dır. Başta ekonomik olmak üzere çeşitli gerekçelerle bu ilin özellikle genç nüfusunu kaybettiğine daha önce değinilmişti. Bunlara ilaveten Afyonkarahisar'da ikamet ettiği halde Kütahya ili nüfusuna kayıtlı olanların araştırma sahasının daha çok neresinden geldiğine bakıldığındaysa, bunların da büyük bir kısmının merkez ilçe nüfusuna kayitlı olduğu görülmektedir. Nitekim TÜİK ADNKS verilerine göre 31 Aralık 2020 tarihi itibarıyla Afyonkarahisar'da ikamet eden 23.733 Kütahya ili nüfusuna kayıtlı kişinin \% 25,8'ini bu ilçe nüfusuna kayıtlı olanlar oluşturmaktadır. Bunu \% 15,6 ile Dumlupınar ve \% 13,6 ile de Altıntaş ilçesi nüfusuna kayıtlı olanlar takip etmektedir. Sözü edilen ilçeler de Afyonkarahisar ili ile sınır komşusudur.

\subsection{Nüfusa Kayıtlı Olunan İllere Göre Kütahya İlinin Göç Açı̆̆ı ve Fazlası Durumu}

31 Aralık 2020 tarihi itibarıyla araştırma sahasında ikamet edip başka bir ilin nüfusuna kayıtlı olanlardan araştırma sahası nüfusuna kayıtlı olup başka illerde yaşayan nüfusun çıkarılmasıyla oluşturulan göç açığı ve fazlası durumunu gösterir tablodan (Tablo 7) da anlaşılacağı üzere Kütahya, ülkenin göç veren illerinden biridir. Kütahya'nın göç açığı verdiği illerin sayısı 26 ve bu iller karşısında verilen göç açığının toplamıysa 197.342 kişidir. İnceleme alanının en çok göç açı̆̆ı verdiği illerse; İzmir (54.686 kişi), İstanbul (31.913 kişi), Bursa (23.791kişi), Manisa (20.084 kişi), Uşak (18.667 kişi), Eskişehir (9.406 kişi), Antalya (9.266 kişi) ve 
Ankara (8.920 kişi)'dır. Nitekim bu 8 ile karşı verilen göç açı̆̆ı, sözü edilen 26 il karşısında verilen toplam göç açı̆̆ının \% 89,5'ine tekabül etmektedir.

Tablo 7. Kütahya İlinin, Ülkenin Diğer İllerine Karşı, Göç Açı̆̆ı ve Fazlası Durumunu Gösterir Tablo (2020)

\begin{tabular}{|c|c|c|c|c|c|}
\hline İlin Adı & Kişi & İlin Adı & Kişi & İlin Adı & Kişi \\
\hline İzmir & -54.686 & Bartın & 37 & Mardin & 396 \\
\hline İstanbul & -31.913 & Isparta & 43 & Artvin & 407 \\
\hline Bursa & -23.791 & Bingöl & 67 & Mersin & 415 \\
\hline Manisa & -20.084 & Batman & 88 & Kırıkkale & 446 \\
\hline Uşak & -18.667 & Iğdır & 112 & Kayseri & 452 \\
\hline Eskişehir & -9.406 & Karabük & 139 & Kırşehir & 502 \\
\hline Antalya & -9.266 & Diyarbakır & 140 & Giresun & 512 \\
\hline Ankara & -8.920 & Bayburt & 148 & Adiyaman & 523 \\
\hline Kocaeli & -4.491 & Gümüşhane & 170 & Ağn1 & 550 \\
\hline Bilecik & -3.345 & Bitlis & 183 & $\overline{\text { Elazı } \breve{g}}$ & 583 \\
\hline Muğla & -2.813 & Gaziantep & 190 & Kars & 693 \\
\hline Aydın & -2.092 & Nevşehir & 193 & Adana & 723 \\
\hline Balıkesir & -1.745 & Erzincan & 202 & Çorum & 774 \\
\hline Tekirdağ & -1.476 & Kastamonu & 245 & Malatya & 819 \\
\hline Denizli & -977 & Siirt & 245 & Yozgat & 835 \\
\hline Sakarya & -912 & Rize & 252 & Kahramanmaraş & 848 \\
\hline Çanakkale & -848 & Kilis & 274 & Ordu & 863 \\
\hline Yalova & -604 & Karaman & 278 & Tokat & 953 \\
\hline Şırnak & -308 & Çankırı & 316 & Samsun & 1.017 \\
\hline Edirne & -298 & Şanlıurfa & 325 & Trabzon & 1.043 \\
\hline Kirklareli & -235 & Sinop & 329 & Niğde & 1.093 \\
\hline Düzce & -187 & Aksaray & 332 & Van & 1.209 \\
\hline Hakkâri & -142 & Amasya & 332 & Sivas & 1.215 \\
\hline Burdur & -71 & Hatay & 336 & Erzurum & 1.431 \\
\hline Bolu & -37 & Osmaniye & 374 & Konya & 1.451 \\
\hline Tunceli & -28 & Muş & 377 & Afyonkarahisar & 7.111 \\
\hline Zonguldak & 36 & Ardahan & 384 & Toplam & 164.331 \\
\hline
\end{tabular}

Kaynak: TÜİK ADNKS "Nüfusa Kayıtlı Olunan İle Göre İkamet Edilen İl ve İkamet Edilen İle Göre Nüfusa Kayıtlı Olunan Ill” veri tabanından yararlanılarak hesaplanmıştır.

Bunlardan başka araştırma sahasının göç açı̆̆ı verdiği diğer iller; Kocaeli, Bilecik, Muğla, Aydın, Balıkesir, Tekirdağ, Denizli, Sakarya, Çanakkale, Yalova, Şırnak, Edirne, Kırklareli, Düzce, Hakkâri, Burdur, Bolu ve Tunceli'dir. Adı geçen illerden Şırnak, Hakkâri ve Tunceli hariç hepsinin ülkenin batısında bulunması, sahadan yapılan göçlerin istikametinin de bu yöne doğru olduğunu göstermektedir (Harita 4).

Yukarı değinilen 26 il dışında araştırma sahasının, ülkenin diğer 54 iline karşı göç fazlası bulunmaktadır. Bu illere karşı araştırma sahasının toplam göç fazlası, 33.011 kişidir. Bunların en başta gelenleriyse; Afyonkarahisar (7.111 kişi), Konya (1.451 kişi), Erzurum (1.431 kişi), Sivas (1.215 kişi), Van (1.209 kişi), Niğde (1.093 kişi), Trabzon (1.043 kişi), Samsun (1.017 kişi) ve Tokat (953 kişi) illeridir.

Kütahya ilinin verdiği toplam göç açı̆̆ı sayısı olan 197.342 kişi ile göç fazlası olan 33.011 kişi çıkarıldığında, aradaki farkın 164.331 olduğu görülmektedir. Bu iki veri birbiri ile karşılaştırıldığındaysa, arada yaklaşık 6 kat $(5,98)$ fark olduğu sonucuyla karşılaşılmaktadır. Bu da ilin nüfus bilançosunun, ne kadar açık verdiğini göstermesi açısından önemlidir.

Sahanın gerek kendi içinde meydana nüfus hareketlerinin ve gerekse başka yerlere verdiği göçlerin nedenleriyle ilgili Kütahya il genelinde bir anket çalışması yapılmıştır. Toplam 1.851 kişinin katıldığ bu çalışmaya göre ekonomik sorunlar ve işsizliğin, bu göçlerin en önemli sebebi olduğu tespit edilmiştir. Anket sonuçlarına göre; eğitim ve sağlık hizmetlerine erişim konusunda yaşanılan sıkıntılar ikinci, büyük yerleşim 
yerlerinin sosyal ve kültürel açıdan daha çekici olması ise göçlerin üçüncü sebebi olarak saptanmıştır (Zafer Kalkınma Ajans1, 2017: 1-3). Bu sorunlarınsa daha çok köy, kasaba gibi kırsal yerleşmelerde etkili olduğu düşünülecek olursa, buralardan şehirlere doğru göçlerin yaşandığı çıkarımında bulunmak mümkündür.

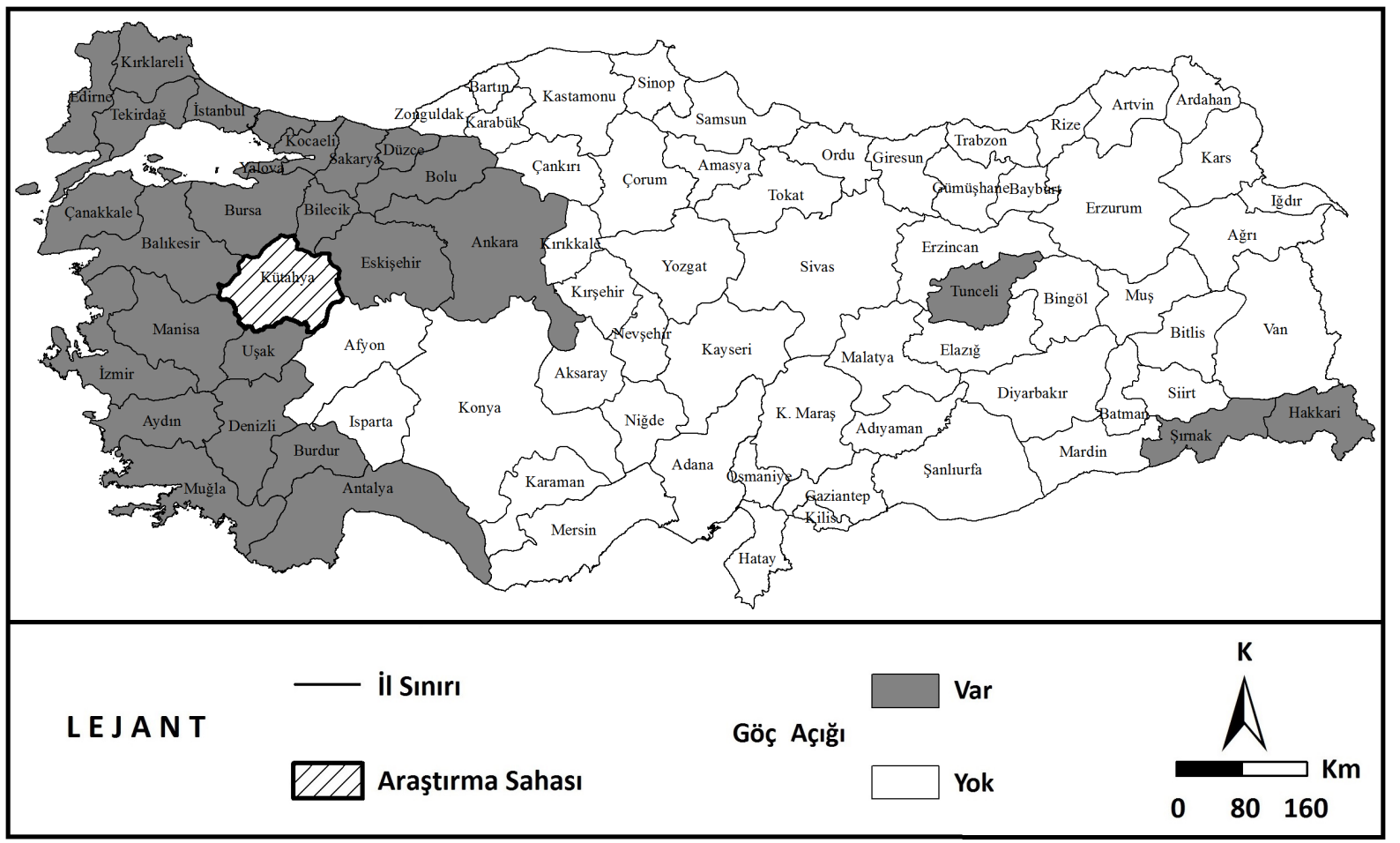

Harita 4. Kütahya İlinin, Ülkenin Diğer İllerine Karşı, Göç Açığı ve Fazlası Durumunu Gösterir Harita (2020)

Göç olayında çıkıs yeri ile varıș yeri arasında, araya giren firsatlar veya engeller nedeniyle göçe ara verilip, engel veya firsatların ortadan kalkmasıyla onun tekrar sürdürülmesi, kademeli göç olarak adlandırılmaktadır (Tümertekin ve Özgüç; 2015, s. 297). Buna göre inceleme alanındaki köy ve kasabaların önce kademeli göçün ilk basamağı olarak nitelendirilebilecek; idari, ekonomik ve kültürel fonksiyon açısından etkisi altında bulundukları; Tavşanlı, Simav, Gediz, Emet ve Kütahya gibi inceleme alanı dâhilindeki şehirlere göç verdiği söylenebilir.

Nitekim sahanın kırsal ve kentsel nüfusunu gösteren tablo ve şekilde (Tablo 8, Şekil 4) de görüleceği üzere 1927 yılında inceleme alanındaki nüfusun \% 83,5'i kırsal alanda yaşıyorken bu oran, 1950 yılına gelindiğinde \% 85,8'e kadar çıkmıştır. Ancak bu yıldan sonra bir gerileme sürecine giren sahadaki kırsal nüfus, nihayet 2020 yılına gelindiğinde \% 28,1'e kadar gerilemiştir. Buna karşın 1950 yılında \% 14,2 olan sahadaki kentsel nüfus ise 2020 yılına gelindiğinde \% 71,9'a kadar yükselmiștir. Dahası mevcut şartların devam etmesi durumunda kentsel nüfus oranının daha da artacağı çıkarımında bulunmak mümkündür.

Kırsaldan yapılan göçler; özellikle 1950’li yıllarda tarımda makineleşmeyle başlamış, daha sonra da devletin tarım kesiminden desteğini çekmesi, kamu hizmetlerinin ve sanayi yatırımlarının ağılıklı olarak büyük kentlerde konuşlanması, toprak iyeliğinde meydana gelen artışla beraber ziraat yapılan topraklarının aşırı derecede parçalanması gibi faktörlerin itici etkisiyle zirve noktasına ulaşmıștır. Bundan başka daha önceden kente göç edenlerin verdikleri bilgi ve desteklerin yanı sıra ulaşım ve iletişim alanında yaşanan gelişmelerin de bu yer değiştirmeler üzerinde etkisi olmuştur (Özdemir, 2012: 2).

Kademeli göçün ikinci ayağı ise bir müddet sonra birinci basamak şehirlerindeki engel veya firsatların ortadan kalkması üzerine gerçekleşmiştir. Bu göçe katılanların hedefindeyse; İzmir, İstanbul, Bursa, Manisa, Uşak, Eskişehir, Antalya, Ankara ve Kocaeli gibi sahanın net göç açığının fazla olduğu; illerin olduğunu söylemek mümkündür. İkinci kademe göçleri üzerinde, araştırma sahasındaki sanayi yatırımlarının, artan il nüfusunun istihdam ihtiyacını yeterince karşılayamamasının etkisi olmuştur. Dahası 2004 yılından başlayarak Kütahya ilinde binlerce kișiye istihdam sağlayan kamu iktisadi teșebbüslerinin özelleștirilmesi, sahadan yapılan göçlerin hızını önemli ölçüde artırmıştır. 
Tablo 8. Sayım Yıllarına Göre Kütahya İlinin Kırsal ve Kentsel Nüfusu ile Bunların Oranlarını Gösterir Tablo (1927-2020)

\begin{tabular}{||c|c|c|c|c|c||}
\hline \multirow{2}{*}{ Yıl } & \multicolumn{2}{|c|}{ Kirsal } & \multicolumn{2}{c||}{ Kentsel } & \multirow{2}{*}{ Toplam } \\
\cline { 2 - 5 } & Nüfus & \%'si & Nüfus & \%'si & \\
\hline 1927 & 179.695 & 83,5 & 35.483 & 16,5 & 215.178 \\
\hline 1935 & 212.718 & 84,9 & 37.738 & 15,1 & 250.456 \\
\hline 1940 & 221.460 & 85,4 & 37.845 & 14,6 & 259.305 \\
\hline 1950 & 262.024 & 85,8 & 43.338 & 14,2 & 305.362 \\
\hline 1960 & 294.781 & 80,2 & 72.972 & 19,8 & 367.753 \\
\hline 1970 & 329.758 & 75,0 & 110.209 & 25,0 & 439.967 \\
\hline 1980 & 335.058 & 67,4 & 162.031 & 32,6 & 497.089 \\
\hline 1990 & 336.021 & 58,1 & 241.999 & 41,9 & 578.020 \\
\hline 2000 & 338.034 & 51,5 & 318.869 & 48,5 & 656.903 \\
\hline 2010 & 206.924 & 35,0 & 383.572 & 65,0 & 590.496 \\
\hline 2020 & 161.878 & 28,1 & 414.810 & 71,9 & 576.688 \\
\hline
\end{tabular}

Kaynak: DİE’nin Genel Nüfus Sayımı sonuçları ile TÜİK ADNKS’nin “Köy/Şehir” veri tabanından yararlanılarak hesaplanmıştır.

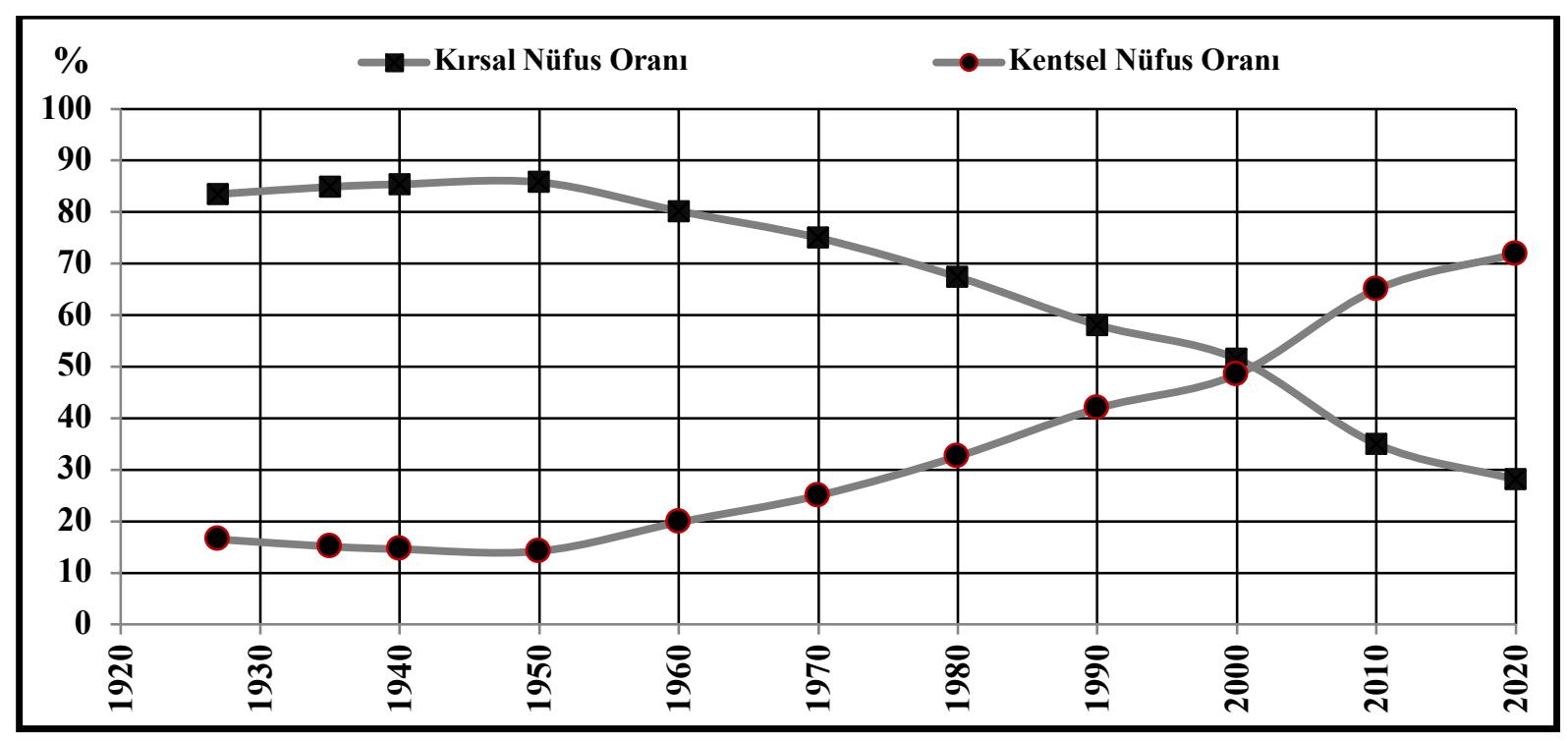

Şekil 4. Sayım Yıllarına Göre Kütahya İlinin Kırsal ve Kentsel Nüfus Oranlarını Gösterir Grafik (1927-2020)

Nitekim 2004 yılında Eti Gümüş A.Ş., Kütahya Gübre Sanayi A.Ş., Kütahya Azot Fabrikası (TÜGSAŞ), Kütahya Şeker Fabrikası A.Ş. özelleştirilirken bunları 2009 yılında Osmangazi Elektrik Dağıtım A.Ş., 2011 yılında Kütahya Manyezit İşletmeleri (TBMM, 2013), 2012 y1lında Seyitömer Termik Santralı (Resmî Gazete, 2013) ve 2014 yılında da Tunçbilek Termik Santralı (Resmî Gazete, 2015) takip etmiştir.

Özelleştirme sonrasında göç verme süreci, benzer durumda olan ülkenin diğer illerinde de görülmüştür. Nitekim kamu sanayi yatırımlarına dayalı olarak geçmiş dönemlerde büyüme süreci yaşamış yerleşim birimlerinin, kamunun bu alandan çekilmesiyle ekonomik ve sosyal açıdan bir gerileme süreci içine girdiği bilinmektedir (Özaslan, 2011: 333). Zira yapılan özelleştirmeler, çalışanların iş ve gelir güvencesini ortadan kaldırmaktadır (Çelik, 1995: 24). Gerçekten de Türkiye'de özelleştirilen 24 kuruluşun durumlarının incelendiği bir çalışma; özelleştirme öncesinde 65.361 çalışanı olan işletmelerin, özelleştirme sonrasında bu sayıyı 49.900'a düşürdüğünü göstermiştir (Şanöz, 2007: 146). Bu şekilde işten çıkarılan kişiler ve onların aileleri, ciddi ekonomik sıkıntılarla yüz yüze gelmekte ve onları gelecek korkusu sarmaktadır. Dahası bu şekilde işinden olanlar, kendilerine ödenmesi gereken tazminatların bile tam olarak ödenmediğini ve bunun da iş mahkemelerinde açılan dava sayılarını önemli ölçüde artırdığını ifade etmişlerdir (Kurt, 2020: 56-60). Ve tüm bunlar da özelleştirme yapılan diğer illerde olduğu gibi araştırma sahasından da göçe sebep olmuştur. 
Kütahya ilinin özelleștirme sonrasında büyük oranda göç verdiğini, sayım yıllarına göre saha nüfusunu gösteren Tablo 1 ve sayım yıllarına göre sahanın net göçlerini gösteren Tablo 2'de doğrulamaktadır. Zira bu tablolarda, özellikle 2000 yılından sonra nüfusun dönemsel değişiminde ve net göçlerinde eksi değerler görülmektedir. Nüfusun dönemsel değişiminde, 2000-2007 yılları arasında \% 11,1 oranıyla büyük bir azalma yaşanmış ve bu süreçte Kütahya ilinde (Eti Gümüş A.Ş., Kütahya Gübre Sanayi A.Ş., Kütahya Azot Fabrikası (TÜGSAŞ) ve Kütahya Şeker Fabrikası A.Ş. olmak üzere) 4 büyük özelleştirme yapıllmıştır. Bu özelleştirmeleri takiben özellikle 2007-2010 yılları arasında geçen 3 yıllık süreçte de ilin net göçlerinde, 15.130 kişilik tarihsel bir açık verilmiştir.

Kütahya ilinde yapılan özelleştirmeler, 2010-2015 yılları arasında da devam etmiştir. Nitekim bu zaman diliminde araştırma sahasında (Kütahya Manyezit İsletmeleri, Seyitömer Termik Santralı ve Tunçbilek Termik Santralı olmak üzere) 3 büyük özelleştirme yapılmış ve buna bağlı olarak da belirtilen zaman diliminde ilin net göçlerinde, 8.316 kişilik bir açık daha meydana gelmiştir.

\section{Sonuç}

1927-2020 yılları arasında Türkiye nüfusu yaklaşık 6,13 kat artarken Kütahya ilinin nüfusu ise sadece 2,17 kat artmıştır. 1975 ilâ 2020 yılları arasındaki net göç sayısına göre Kütahya, Afyonkarahisar'dan sonra Ege Bölgesi'nin en fazla göç veren ikinci ilidir. Bundan başka 31 Aralık 2020 tarihi itibarıyla başka bir ile kayıtlı olduğu halde araştırma sahasında ikamet eden nüfustan, araştırma sahası nüfusuna kayıtlı olduğu halde başka illerde yaşayan nüfus arasındaki farka bakıldığında, Kütahya ilinin 164.331 kişilik bir göç açı̆ğ olduğu görülmektedir. Birkaç il hariç, inceleme alanının göç açığı verdiği illerin hepsinin ülkenin batısında olması, sahadan yapılan göçlerin istikametinin de bu yöne doğru olduğunu göstermektedir.

Kütahya ilinin gerek kendi içinde meydana gelen nüfus hareketlerinde ve gerekse başka yerlere verdiği göçlerde sırasıyla; işsizlik ve ekonomik sorunlar, eğitim ve sağlık hizmetlerine erişim konusunda yaşanan sıkıntılar ile büyük yerleşim yerlerinin sosyal ve kültürel açıdan daha çekici gelmesi gibi sebepler etkilidir. Bu sorunların daha çok köy ve kasaba gibi kırsal yerleşmelerde görüldüğü düşünülecek olursa, buralardan şehirlere doğru göçlerin yaşandığı çıkarımında bulunmak da mümkündür. Nitekim kırsal ve kentsel nüfus açısından ilin geçmişine bakılacak olursa, kırsal nüfus oranının 1950 yılında \% 85,8 iken 2020 yılına gelindiğinde \% 28,1'e kadar gerilemesi de bunu doğrulamaktadır. Buna göre il içinde meydana gelen göçler nedeniyle; Kütahya, Tavşanlı, Simav, Emet ve Gediz gibi şehirlerin nüfusu artmıştır. Bunun sonucunda inceleme alanındaki kentsel nüfus oranı 1950 yılında \% 14,2 iken 2020 yllına gelindiğinde ise \% 71,9'a kadar çıkmıştır.

Saha dışına yapılan göçler ise daha çok; İzmir, İstanbul, Bursa, Manisa, Uşak, Eskişehir, Antalya, Ankara ve Kocaeli gibi illere yapılmıştır. İnceleme alanındaki sanayi yatırımlarının artan il nüfusunun istihdam ihtiyacını yeterince karşılayamaması, bu göçlerin başlıca sebebidir. Dahası 2004 yılından başlayarak ilde binlerce kişiye istihdam sağlayan kamu iktisadi teşebbüslerinin özelleştirilmesi, bu göçlerin hızını önemli ölçüde artırmıştır. Nitekim nüfusun dönemsel değişiminde, 2000-2007 yılları arasında \% 11,1 oranıyla büyük bir azalmanın görüldüğü süreçte Kütahya ilinde 4 büyük özelleştirme yapılmıştır. Bu özelleştirmeleri takiben özellikle 2007-2010 yılları arasında geçen 3 yıllık süreçte de ilin net göçlerinde, 15.130 kişilik tarihsel bir açık verilmiştir. Bundan başka sahada 3 büyük özelleştirmenin daha yapıldığı 2010-2015 yılları arasındaki zaman diliminde de Kütahya ilinin net göçlerinde, 8.316 kişilik bir açık daha meydana gelmiştir. 


\section{KAYNAKÇA}

Adıgüzel, Y. (t. y.). Küreselleşme Çă̆ında Göç. İstanbul Üniversitesi AUZEF. 21 Şubat 2021 tarihinde http://auzefkitap.istanbul.edu.tr/kitap/sosyoloji lisans ao/kuresellesme caginda goc.pdf adresinden erişildi.

Akgüngör, S., Kumral, N., Çelik, N. (2017). Ekonomik ve Demografik Göstergelerle İzmir. İzmir: EGİAD.

Aktaş, H. ve Karğın M. (2019). Manisa ekonomik görünüm raporu. Manisa: TOBB-Manisa Oda ve Borsalar Akademik Danışmanlık Projesi. Erişim adresi https://www.manisatso.org.tr/dosyalar/suresizyayinlar/Manisa-Ekonomik-Raporu.pdf

Ankara Kalkınma Ajansı. (2018). Ankara el kitabı, Ankara: Ankara Kalkınma Ajansı.

Aydemir, B. (2005, Kasım). Balıkesir ekonomisi; sektörel gelişmeler, uygun yatırım alanları, gelişme için çözüm önerileri. Balıkesir 2005 Sempozyumu Bildiriler Kitabı, Balıkesir.

Aydın, İ. (2004). Demirci ilçesinin ekonomik yapısı. (Yayımlanmamış doktora tezi). İstanbul Üniversitesi, İstanbul.

Barış, S. (2019). 21. Yüzyılda Tokat'in ekonomik görünümü: TR83 ve Türkiye geneli ile bir karşılaştırma. Anemon Muş Alparslan Üniversitesi Sosyal Bilimler Dergisi, 7(1), 111-124.

Bozkurt, Y. (2011). Türkiye’de nüfus hareketliliği ve Kütahya örneği. Dumlupınar Üniversitesi Sosyal Bilimler Dergisi, 30, 291-300.

Bozyiğit, R. ve Güngör, Ş. (2011). Konya Ovası'nın toprakları ve sorunları. Marmara Coğrafya Dergisi, 24, 169-200.

Çavuş, V., Kurt, R., Tomak, E. D., Karademir, A. ve Ertaş, M. (2013, Haziran). Mobilya sektörünün Bursa ekonomisindeki yeri ve önemi. Bursa 4. Kent Sempozyumu, Bursa.

Çelik, N. (1995). Özelleştirme kapat kurtul politikasına dönüşmemelidir. Çerçeve, 4(13), 24.

Çetintaş, E. (2017). Cumhuriyetten Bu Yana Kütahya'da Sanayi Devrimleri. 9 Şubat 2021 tarihinde https://www.kutso.org.tr/wp-content/uploads/2017/06/sanayi-devrimleri.pdf adresinden erişildi.

Darkot, B. (1967). Şehir ayrımında nüfus sayısı ve fonksiyon kriterleri. İstanbul Üniversitesi Coğrafya Enstitüsü Dergisi, 8(16), 3-8.

Demireli, C. ve Taşkın, E. (2013). Üniversite öğrencilerinin bulundukları şehre ekonomik katkıları: Kütahya il merkezi örneği. Dumlupınar Üniversitesi Sosyal Bilimler Dergisi, 37, 321-328.

Deniz, M. (2014). Ulaşım sistemleri ve Uşak. Doğu Coğrafya Dergisi, 19(32), 1-26. doi: 10.17295/dcd.71556

Doğanay, H. (1986). Trabzon'da nüfus hareketleri ve göçler. Atatürk Üniversitesi Fen Edebiyat Fakültesi Araştırma Dergisi, 15, 281-304.

Duysak A., Ceylantekin, R., Karaca, E., Akkaş, M. (2014). Kütahya çinisinin markalaşma ve pazarlanması fizibilite etüdü. Kütahya: Zafer Kalkınma Ajansı.

Elmastaş, N. ve Yılmaz. S. (2015). Van ilinde göçler. Turkish Studies, 10/10, 403-428. doi: http://dx.doi.org/10.7827/TurkishStudies.8540

Erkan, R. ve Aydın, D. (2010). Güneydoğu Anadolu Bölgesi illerinde bölge içi ve bölge dışı göç eğilimleri. Aile ve Toplum, 6(22), 31-46.

İssi, A. ve Yurdakul, H. (2002). Kütahya çiniciliği ve günümüzdeki sorunları. Dumlupınar Üniversitesi Fen Bilimleri Enstitüsü Dergisi, 3, 73-81.

Karaman, S., Aydemir, B., Kılıç, S. N. (2019). Balıkesir turizm envanteri ve strateji çalışması. Balıkesir: Balıkesir Üniversitesi. Erişim adresi https://www.gmka.gov.tr/dokumanlar/yayinlar/Balikesir-TurizmEnvanteri-Strateji-Calismasi.pdf

Kurt, A. (2020). Türkiye'de özelleştirmenin ekonomik boyutu ve işçi sendikalarının özelleştirmeye yaklaşımlarına yönelik bir inceleme. Uygulamalı Sosyal Bilimler Dergisi, 4(1), 48-75. 
Küçükali, A. (2018). Akademisyenlerde göç etme niyeti: Erzurum ili örneği. HAK-iŞ Uluslararası Emek ve Toplum Dergisi,7(19), 588-608. doi: 10.31199/hakisderg.471253

Meçik, O., Genç, E., Karabacak, M., (2013). Uşak ekonomisi ve yerel dinamiklerin rolü. Uşak Üniversitesi Sosyal Bilimler Dergisi, 6, 48-69.

Mert, Z. G., Albayrak, A. N., Karabulgu, S., Uluer Topuz, Ö. (2005). Kocaeli'nde sanayinin gelişimi. Mimarizm Kocaeli Mimarlar Odası Dergisi, 43-48.

MTA. (2010). Kütahya İli Maden ve Enerji Kaynakları. Erişim adresi https://www.mta.gov.tr/v3.0/sayfalar/bilgimerkezi/maden potansiyel 2010/kutahya madenler.pdf

OECD. (2008). Istanbul, Turkey. OECD Territorial Reviews.

Özaslan, M. (2011). Ankara ekonomisinde gerileme eğilimleri ve yeni yol arayışları. Ç. Ü. Sosyal Bilimler Enstitüsü Dergisi, 20(2), 331-364.

Özdemir, H. (2012). Türkiye'de iç göçler üzerine genel bir değerlendirme. Akademik Bakış Dergisi, 30, 1-18.

Özgür, E. M. (1994). Bilecik ilinde farklı karakterde iki şehir: Bilecik ve Bozüyük. Türkiye Coğrafyası Araştırma ve Uygulama Merkezi Dergisi, 3, 179-191.

Resmî Gazete. (2013, 15 Mart). Seyitömer Termik Santrali. 9 Şubat 2021 tarihinde https://www.resmigazete.gov.tr/eskiler/2013/03/20130319-38.htm adresinden erişildi.

Resmî Gazete. (2015, 17 Mart). Orhaneli ve Tunçbilek Termik Santralleri. 9 Şubat 2021 tarihinde https://www.resmigazete.gov.tr/eskiler/2015/03/20150324-4.htm adresinden erişildi.

Şahbaz, H. (2020). Ülke içi göçlerde Eskişehir ilinin yeri. Doğu Coğrafya Dergisi, 25(44), 107-124.

Şanöz, F. (2007). Dünyada ve Türkiye'de özelleştirme uygulamaları: Türkiye’deki özelleştirme uygulamalarının başarısının ölçülmesi. (Yayınlanmamış Yüksek Lisans Tezi). Gazi Üniversitesi Sosyal Bilimler Enstitüsü, Ankara.

Şen, M. (2014). Trabzon'dan İstanbul'a göç edenlerin sosyo-ekonomik analizi. ÇSGB Çalışma Dünyası Dergisi, 2(3), 46-61.

TBMM. (2013, 22 Mayıs). TBMM Genel Kurul Tutanağı 24. Dönem 3. Yasama Yılı 108. Birleşim. 9 Şubat 2021 tarihinde https://www.tbmm.gov.tr/develop/owa/tutanak_g_sd.birlesim baslangic?P4=21952\&P5=H\&page1=18 \&page $2=18$ adresinden erişildi.

Toksöz, G. (2011). Antalya ili işgücü piyasası analizi. Ankara: Uluslararası Calışma Orgutu (ILO) Turkiye Ofisi. Erişim adresi http://www.ilo.org/public/turkish/region/eurpro /ankara/info/antalya-isgucu.pdf

TÜIKK. ADNKS (Adrese Dayalı Nüfus Kayıt Sistemi) Sonuçlarl. 6 Şubat 2021 tarihinde, https://biruni.tuik.gov.tr/medas/?kn=95\&locale=tr adresinden erişildi.

TÜIK. Göç Istatistikleri Veritabant. $12 \quad$ Mayı $2021 \quad$ tarihinde, https://tuikweb.tuik.gov.tr/PreTablo.do?alt $\mathrm{id}=1067$ adresinden erişildi.

TÜİK. Temel İstatistikler: Illlerin Aldı̆̆ı, Verdiği Göç, Net Göç ve Net Göç Hızı, Genel Nüfus Sayımları-ADNKS. 12 Mayıs 2021 tarihinde, https://tuikweb.tuik.gov.tr/UstMenu.do?metod=temelist adresinden erişildi.

TÜİK. Ulusal Eğitim Istatistikleri Veritabant. $6 \quad$ Şubat 2021 tarihinde, $\mathrm{http} / / /$ biruni.tuik.gov.tr/medas/?kn=130\&locale=tr adresinden erişildi.

Tümertekin, E. ve Özgüç, N. (2015). Beşeri Coğrafya İnsan Kültür Mekân. İstanbul: Çantay Kitabevi.

Türkşeker. (t. y.). Tarihçemiz. Erişim adresi https://www.turkseker.gov.tr/?ModulID=3\&MenuID=3

Ulukapı, K. ve Şener, S. (2017). Antalya ilinin organik bitkisel üretim potansiyelinin dünya ve Türkiye ile kıyaslanması ve gelişmesine yönelik öneriler. Nevşehir Bilim ve Teknoloji Dergisi, 6, 271-279. doi: 10.17100/nevbiltek.322983

Yakar, M., Saraçlı, S., Yazıcı, H. (2010). Afyonkarahisar İlinde iller arası göçlerin gelişmişlik endeksleriyle analizi. Doğu Coğrafya Dergisi, 15(24), 255-271.

Yavuz, O. (1993). Erzurum'dan göç sorunu, nedenleri, sonuçları ve çözüm yolları. Tarım Ekonomisi, 2, 10-21. 
Yener, L. (1980). Türkiye madenciliği-79. Bilimsel Madencilik Dergisi, 19(1), 7-107.

Yılmaz, C. ve Zeybek, H. İ. (2016). Samsun Coğrafyası. Samsun: Canik Belediyesi Kültür Yayınları.

Zafer Kalkınma Ajansı. (2017). Ek: Kütahya İli Göç Nedenleri Çalışması Değerlendirme Bölümü. Erişim adresi https://www.kutso.org.tr/wp-content/uploads/2017/10/K\%C3\%9CTAHYA-\%C4\%B0L\%C4\%B0G\%C3\%96\%C3\%87-NEDENLER\%C4\%B0-RAPORU.pdf 